\title{
The nudibranchs (Gastropoda Heterobranchia) of the central- eastern coast of Sicily I: Suborder Cladobranchia
}

\author{
Andrea Lombardo \\ Department of Biological, Geological and Environmental Sciences - University of Catania, 95124 Catania, Italy; e- \\ mail: andylombardo94@gmail.com
}

\begin{abstract}
Through this study, new information on the biology of the cladobranch species found from 2017 to the first months of 2021 along the central-eastern coast of Sicily, are provided. After a brief description of this group of nudibranchs, for each species data on morphology, abundance, location and depth, substrates and habitats, seasonality and remarks are here given. Moreover, two new findings of species (Berghia sp. and Trinchesia $\mathrm{cf}$. diljuvia), for the examined area and the Mediterranean basin respectively, are here reported. Still, during this study, two unidentified specimens were encountered.

Along the central-eastern coast of Sicily is present about the $30 \%$ of all Mediterranean cladobranch species. Consequently, considered the small extension of this area, the central-eastern coast of Sicily seems to possess a high level of biodiversity regarding this group of marine heterobranchs.
\end{abstract}

KEY WORDS Cladobranchia; Marine Heterobranchia; New reports; Nudibranchia; Sicily.

Received 31.07.2021; accepted 29.10.2021; published online 18.12.2021

\section{INTRODUCTION}

Willan \& Morton (1984) were the first authors who coined the term "Cladobranchia" to identify all the nudibranchs that present the anus located on the right side of the body, and peculiar "gills" produced by the tegument protrusions. At global scale, within this group of marine gastropods are present about 1000 species (Goodheart, 2017). The groups of nudibranchs that present these characteristics and thus were placed within this suborder were three: Aeolidacea, Dendronotacea and Arminacea (Willan \& Morton, 1984; Goodheart, 2017). These three groups were erected by Odhner (1934) according to the presence of certain characteristics, almost all easily observable from the external morphology of the animals. The aeolidaceans are characterized by possessing, on the dorsal surface of the body, some tegument claviform eversions called cerata; these last structures present in their interior the digestive gland branches and possess a peculiar structure on their apex called cnidosac. This structure serves to store and reuse the nematocists, obtained through the diet, against any predators. These nudibranchs, generally, have a narrow and elongated foot, which is perfectly adapted to creep above arborescent substrates like hydrozoans and sea-anemones on which these animals feed (Willan \& Morton, 1984). Moreover, the eolids have sessile eyes, well distinct cephalic tentacles, absence of oral veil and the anus is located laterally or latero-dorsally (Odhner, 1934; Willan \& Morton, 1984).

According to Odhner $(1934 ; 1936)$, the dendronotaceans are easily distinguishable from the others cladobranchs for the presence of peculiar rhinophores' sheaths, inside of which the rhinophores can be retracted. Considering the external morphology of this group, two other characters can be found in these animals: the occurrence of tentacular extensions on the oral veil (not always present) (Wägele 
\& Willan, 2000) and of dendritic tuft shaped gills on each side of the notum (not always present) (Willan \& Morton, 1984). In these nudibranchs, the anus is laterally or latero-dorsally located (Odhner, 1934; Willan \& Morton, 1984). Like the previous group, also dendronotaceans can present cerata (Odhner, 1936; Willan \& Morton, 1984).

The arminaceans are considered as the most basal group of the cladobranchs (Wägele \& Willan, 2000). They are characterized by two distinct morphological forms. In the first form there is a large and pustulose or longitudinally ridged notum, an evident crescent-shape oral veil, retractable rhinophores and in front of these last, a sensory organ called caruncle can be present (Lance, 1962; Franc, 1968; Thompson \& Brown, 1984; Miller \& Willan, 1986). In these animals, tegument eversions, which contain the digestive gland branches and are used even as gills, are located under the edges of the notum (Willan \& Morton, 1984). In the other form, the body has a shape similar to that of eolids, possessing many cerata on the notum, even in front of the head. The rhinophores are not retractable and between them can be present an evident sensory caruncle (PruvotFol, 1954; Franc, 1968; Willan \& Morton, 1984; Miller \& Willan, 1986).

Actually, the abovementioned division of the suborder Cladobranchia in three groups is not anymore formally accepted. In fact, Bouchet et al. (2017) highlighted that, although this group seems to be monophyletic through phylogenetic analyses conducted by Goodheart (2017), some groups within this suborder have not yet been supported by molecular phylogeny studies. Consequently, nowadays, the suborder Cladobranchia is divided in nine superfamilies (Bouchet et al., 2017): Arminoidea Iredale \& O’Donoghue, 1923 (1841); Doridoxoidea Bergh, 1899; Proctonotoidea Gray, 1853; Tritonioidea Lamarck, 1809; Dendronotoidea Allman, 1845; Flabellinoidea Bergh, 1889; Fionoidea Gray, 1857; Aeolidioidea Gray, 1827 and [unassigned] Cladobranchia.

Nevertheless, the "traditional classification" of Odhner (1934) is anyway useful to easily place a cladobranch in a given systematic group, when it is encountered during any scuba dives. In fact, in some books on nudibranchs, published in the last years, they refer almost always to the three groups highlighted by Odhner (1934) (Trainito \& Doneddu, 2014; Burn, 2015; Naya-Garmendia, 2016).
Recently, Lombardo \& Marletta (2020a) produced the first list of the marine heterobranchia fauna along the central-eastern coast of Sicily. Through this list it can be noted that, in this area, there are 34 species belonging to the suborder Cladobranchia. Despite Lombardo and Marletta (2020a) provided information on the localities and depths at which the various species of cladobranchs were found, they did not provide data about the biology and ecology of these animals. Consequently, the aim of this study is to give new information on the cladobranch species found by the authors along the central-eastern coast of Sicily (Ionian Sea), and thus to deepen the knowledge of this group of marine gastropods in this particular area of the Ionian coast of Sicily.

\section{MATERIAL AND METHODS}

This study was conducted throughout 2017 to March 2021 in five areas located along the centraleastern coast of Sicily. The two southernmost sites are Ognina (37'31'50.4' N - 15'07'10.8' E) and Bellatrix $\left(37^{\circ} 32^{\prime} 03.2^{\prime \prime} \mathrm{N}-15^{\circ} 07^{\prime} 35.2^{\prime \prime} \mathrm{E}\right)$, both located in the municipality of Catania. Either are subjected to a strong anthropic pressure due to the large amount of apartment buildings and bathing establishments present along the entire area. Moreover, in their proximity there are a wastewater outfall and a harbour. Given the similar environmental conditions and their proximity (about $540 \mathrm{~m}$ ), these sites are here considered as a single site called Catania. The two northernmost sites are Scalo Pennisi (37³8'23.2” N - 15¹1'04.6" E) and Acque Fredde (37 $38^{\prime} 15.7^{\prime \prime} \mathrm{N}-15^{\circ} 10^{\prime} 52.1^{\prime \prime}$ E), both located in the hamlet of Santa Tecla (within the municipality of Acireale). These sites present the most natural conditions among those examined during this study. Consequently, because of their proximity (about $390 \mathrm{~m}$ ) and the environmental similarities, these two sites are here considered as a single site called Santa Tecla. The site of Santa Maria La Scala is located between the northernmost and the southernmost sites. This site is situated in the homonymous hamlet of the municipality of Acireale and present intermediate environmental conditions between Catania and Santa Tecla.

During this study, 322 scuba dives (124 in Catania, 102 in Santa Maria La Scala and 96 in Santa Tecla) were conducted. The dives have been carried out between 9:00 and 11:30 a.m., all year round, 
two times per week (marine-weather conditions allowing). For each examined site, the same underwater path was followed, according to the seabed geomorphology (nearly always between 0 and 45 $\mathrm{m}$ of depth). During the dives, all the encountered cladobranch specimens were photographed through an Olympus TG-4 underwater camera. Then, the photographs were examined and all the data regarding the species, the depth, the substrate, the period of the year and any further observations were registered. For the identification of cladobranch species the following texts was mainly consulted: Schmekel and Portmann (1982), Trainito and Doneddu (2014). Regarding the identification of phytobenthos, the algal species were examined in the laboratory using the identification keys of Cormaci et al. $(2012 ; 2014 ; 2017 ; 2020)$. Moreover, for the identification of zoobenthos the text principally used was Trainito \& Baldacconi (2014). For each cladobranch species included in this study, the following information are provided: Morphology, Abundance, Location and depth, Substrates and habitats, Seasonality and Remarks.

Regarding to the information on species' abundance some definitions are here given: "rare" indicates those species that are encountered once in a while or are very difficult to find; "uncommon" refers to species that are not seen on every dive or that you have to look for; "common" denotes those species that are encountered almost in all dives and are easy to find for various reasons (colour, behaviour, lifestyle); "very common" designates those species that are like the common ones, but much more numerous and conspicuous. Some species presents intermediate abundance categories.

\section{RESULTS}

\section{Systematics}

\section{Ordo NUDIBRANCHIA}

Subordo CLADOBRANCHIA

Familia TRITONIIDAE Lamarck, 1809

\section{Genus Duvaucelia Risso, 1826}

Duvaucelia manicata (Deshayes, 1853) (Fig. 1)

MoRPHOLOGY. This species presents a rectangular shaped body, longitudinally elongated. It is predominantly grey and almost all the edges of the body are bordered by a white bright line. From the head, on the dorsal surface of the body, there is a black line that continues longitudinally to the posterior extremity of the notum. This stripe is accompanied, on each side of the notum, by a longitudinal discontinuous black line, whose discontinuities almost always match with the bases of the branchial tufts. These two discontinuous lines can present a more or less disordered appearance. In fact, black spots or points can develop alongside them. On each flank there is a narrow black line, which goes from the sides of the head to the posterior part of the body. These flank lines are accompanied, for all their length, by black dots, both above and below them. Dorsally, on each side of the notum there are five-seven branchial tufts. The oral veil possesses six finger-shaped eversions.

ABundance. Through this study, only two specimens were found, consequently D. manicata can be considered as rare in this area.

LOCATION AND DEPTH. This nudibranch was found only in the site of Santa Maria La Scala, at 34 and $5 \mathrm{~m}$ of depth.

Substrates AND habitats. This species was documented above the red alga Peyssonnelia sp. and on the brown alga Dictyota dichotoma (Hudson) J.V. Lamouroux.

Seasonality. D. manicata was found in March and June.

\section{Familia DOTIDAE Gray, 1853}

Genus Doto Oken, 1815

Doto acuta Schmekel et Kress, 1977 (Fig. 2)

MORPHOLOGY. The body is grey-transparent coloured, and, through its tegument, the interior of the animal is easily visible. The rhinophores and the edge of their sheaths have on their surface several bright white dots. The cerata (five to six pairs) are also transparent and, through them, it is possible to note a white-yellow coloration, according to the specimens. The surface of each cerata presents several protrusions, which have a black dot at their tips.

ABUNDANCE. In total, through this study, 16 specimens of $D$. acuta were observed. Consequently, this species can be considered as uncommon.

LOCATION AND DEPTH. This species was documented in all the study areas, between 6 and $34 \mathrm{~m}$ of depth. 
Substrates And habitats. Doto acuta was found on several substrates. Regarding the algal substrates, this species was observed on: Feldmannophycus rayssiae (Feldmann \& G. Feldmann) H. Augier \& Boudouresque covered by diatoms; between filamentous red algae with Jania sp.; Contarinia squamariae (Meneghini) Denizot; Peyssonnelia sp. Covered by hydrozoans; Jania sp. covered by diatoms; mix of filamentous red and brown algae; Halopteris filicina (Grateloup) Kützing; Zonaria tournefortii (J. V. Lamouroux) Montagne and D. dichotoma. Moreover, D. acuta was found on unidentified hydrozoans and bryozoans and on the entoproct Loxosomella sp.

SEASONALITY. This nudibranch was documented for February, March, April, May, June, July and December. The egg masses were observed in April, May and July.

REMARKS. The small sizes of this species make difficult its finding. Consequently, it is probable that this species is more common than observed. The egg masses, ribbon shaped and white coloured, are documented on several algae as: $C$. squamariae; $D$. dichotoma and on thalli of Peyssonnelia sp. covered by hydrozoans.

\section{Doto cervicenigra Ortea et Bouchet, 1989 (Fig. 3)}

MORPHOLOGY. The body is grey-transparent coloured, and, through it, the interior of the animal can be observed. On the head, between rhinophores, there is a black stripe that develops longitudinally in a more or less uniform way. On the surface of the body, rare black scattered blotches can be present. The rhinophores present, on their surface, black spots, and bright white dots. These latter are present also on the edge of the rhinophores' sheaths and on the small oral veil. The cerata (four-five pairs) are transparent and with several protrusions. Their interior is white yellowish.

ABUndANCE. Through this study, only four specimens of $D$. cervicenigra were found. Consequently, it can be considered as rare.

LOCATION AND DEPTH. This species was documented in Santa Tecla and Catania between 5.3 and $20 \mathrm{~m}$ of depth.

Substrates and habitats. Doto cervicenigra was observed above filamentous red algae covered by cyanobacteria and diatoms; on Peyssonnelia sp. covered by diatoms; $D$. dichotoma covered by detritus and hydrozoans and on the sponge Crambe crambe (Schmidt, 1862).

SEASONALITY. Doto cervicenigra specimens were documented in April, May, November and January.

\section{Doto floridicola Simroth, 1888 (Fig. 4)}

MorPhOlOGY. This species presents in general a body grey-transparent coloured. In the middle of the head, on the dorsum and on the flanks, there are red blotches which, joining between them, formed several longitudinal stripes. The rhinophores' sheaths possess the same blotches. The rhinophores have many bright white dots on their surface. The cerata (four-five pairs) are strongly swollen and have several protrusions neatly arranged. Each cerata presents a light yellow, almost pinkish coloration, while the protrusions are light red coloured.

ABUndance. Only two specimens were found during this study, consequently this species can be considered as rare.

LOCATION AND DEPTH. Doto floridicola was found in Santa Maria La Scala and Santa Tecla, at 32.5 and $17.5 \mathrm{~m}$ of depth respectively.

SUBSTRATES AND HABITATS. This nudibranch was exclusively observed on colonies of the hydrozoan Aglaophenia sp.

Seasonality. April and June.

REMARKS. Both the specimens found during this study were observed on the central axis of the hydrozoan Aglaophenia sp.. Moreover, both animals possessed strongly swollen cerata, almost spherical in shape. These two characteristics made this nudibranch easily detectable when present.

\section{Doto maculata (Montagu, 1804) (Figs. 5, 6)}

MorPHOLOGY. The body presents a general greytransparent colouration. Along almost all of the body surface, many small longitudinally elongated crimson blotches can be observed. The edges of the rhinophores' sheaths possess an evident anterior eversion. The head, the rhinophores, the oral veil, the rhinophores sheaths and the genital papilla present on their surface many bright white dots. The cerata (three pairs) are transparent and, through them, the digestive gland's branches, that are yellow- 


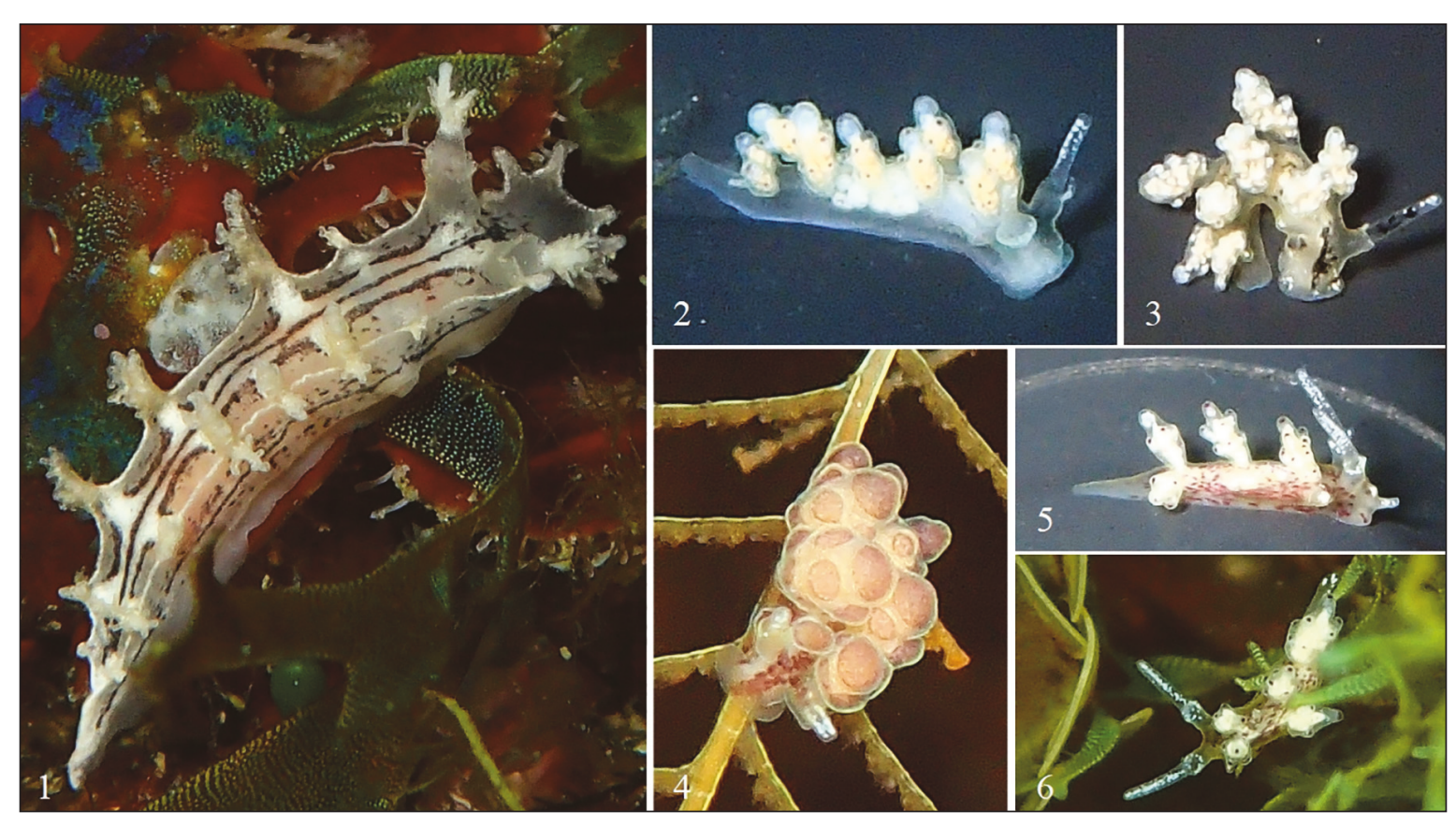

Figures 1-6: Tritoniidae and Dotidae. Fig. 1: Duvaucelia manicata. Fig. 2: Doto acuta. Fig. 3: Doto cervicenigra. Fig. 4: Doto floridicola. Fig. 5: Doto maculata. Fig. 6: the second D. maculata specimen (photos by A. Lombardo).

white coloured, can be noted. They present several protrusions, at whose apex there are an evident black-violet point.

ABUNDANCE. This nudibranch was found only twice (Lombardo \& Marletta, 2021a; present study).

LOCATION AND DEPTH. The animals were documented in Santa Maria La Scala at 5 and $8.4 \mathrm{~m}$ of depth (Lombardo \& Marletta, 2021a; present study).

SubStRATES AND habitats. Doto maculata was observed on a thallus of Halopteris scoparia (Linnaeus) Sauvageau (Lombardo \& Marletta, 2021a) and on D. dichotoma.

Seasonality. Both the specimens were found during May.

Familia JANOLIDAE Pruvot-Fol, 1933

Genus Antiopella Hoyle, 1902

Antiopella cristata (Delle Chiaje, 1841) (Fig. 7)

MoRPHOLOGY. The body, dorso-ventrally flattened, presents an almost elliptical shape. Generally, the animals are orange coloured. This colouration can remarkably vary in shade and trasparency. Usually, the largest specimens have a more opaque tegument, while the smallest ones present a completely transparent tegument. Dorsally there are two thick white longitudinal stripes that are parallel to each other and go from the anterior part of the head to the tail. The cerata are huge and swollen. They are so numerous that often hide almost completely the animal's body. The cerata are transparent and orange coloured. Through them, it is possible to see the thin brown digestive gland's branching. The tip of each cerata possesses an electric blue colouration and it is surrounded by a ring of small bright white dots. The rhinophores are laminated and, between them, there is the caruncle.

ABundance. Throughout this study, 22 specimens were found. This species can be considered as uncommon.

LOCATION AND DEPTH. This species was documented in all the examined areas from 11 to $36 \mathrm{~m}$ of depth (Lombardo \& Marletta, 2020b).

SUBSTRATES AND HABITATS. Antiopella cristata was found on different substrates: red algae covered by detritus, mix of red and brown algae, photophi- 
lous stands, the bryozoans Bugula spp. and the sponge $C$. crambe (Lombardo \& Marletta, 2020b). Moreover, this species was documented on the following algal substrates: Rhodymenia sp.; Sphaerococcus coronopifolius Stackhouse covered by detritus; Peyssonnelia sp.; Asparagopsis armata Harvey; Lithophyllum stictiforme (J.E. Areschoug) Hauck; D. dichotoma; Lophocladia lallemandii (Montagne) F.Schmitz (present study).

SEAsOnality. Apparently, this species would seem to be annual. The animals start to appear in autumn, reaching the peak of presence in winter and in spring, and tend to disappear at the beginning of the summer (Lombardo \& Marletta, 2020b).

REMARKS. The egg masses (Fig. 8) were found in January, March, April, June, July and December on the following substrates: Bugula spp.; Dictyota spp.; on the central axis of Eudendrium sp. covered by bryozoans; on Ericaria zosteroides (C. Agardh) Molinari \& Guiry (Lombardo \& Marletta, 2020b); Bugulina turbinata (Alder, 1857); Jania adhaerens J.V. Lamouroux and Z. tournefortii (present study). Rarely the egg masses, that usually are laid in compact clusters, presented a strongly loose aspect. Moreover, it was observed that the annelid Hermodice carunculata (Pallas, 1766) feeds on the egg masses of $A$. cristata.

\section{Familia FLABELLINIDAE Bergh, 1889}

Genus Edmundsella Korshunova, Martynov, Bakken, Evertsen, Fletcher, Mudianta, Saito, Lundin, Schrödl et Picton, 2017

\section{Edmundsella pedata (Montagu, 1816) (Fig. 9)}

MorPhology. Generally, this species presents an elongated body. Sometimes, depending on the position and the animal's activity, the body can be more or less contracted and swollen. In this case the pericardium area becames very evident, assuming a hump shape. This nudibranch is pink-violet coloured. The tips of the oral tentacles and of the rhinophores are white. These last can be smooth or wrinkled. The base of each cerata starts directly from the notum. The cerata are elongated and transparent. Through them, the orange-coloured digestive gland's ramifications can be noted. At the apex they are grey coloured, with a white ring.

ABUNDANCE. From common to very common.
LOCATION AND DEPTH. Many specimens were found in all examined areas from below the surface of the water to $38.3 \mathrm{~m}$ of depth.

SubSTRATES AND HABITATS. The largest assemblages of $E$. pedata (as well as the egg masses) were observed on Eudendrium spp. colonies (Lombardo et al., 2020). However, this nudibranch can be encountered on many different substrates: mix of red algae with detritus; Rhodymenia sp.; C. squamariae; Lithophyllum sp.; Peyssonnelia sp.; F. rayssiae; Radicilingua reptans (Kylin) Papenfuss; Dasya sp.; turfs of Jania sp. covered by cyanobacteria and diatoms; turfs of Ellisolandia elongata (J. Ellis \& Solander) K. R. Hind \& G. W. Saunders; filamentous red algae; H. filicina; H. scoparia; Lobophora variegata (J. V. Lamouroux) Womersley ex E. C. Oliveira; Z. tournefortii; Dictyota implexa (Desfontaines) J. V. Lamouroux; D. dichotoma (also the egg masses); Cladophora sp. (also the egg masses); Palmophyllum crassum (Naccari) Rabenhorst; Caulerpa cylindracea Sonder; Reptadeonella violacea (Johnston, 1847) (also the egg masses); Schizobrachiella sanguinea (Norman, 1868); Bugula sp.; Myriapora truncata (Pallas, 1766) (also the egg masses); Adeonella calveti Canu \& Bassler, 1930 (also the egg masses) and Dynamena disticha (Bosc, 1802) (also the egg masses). A specimen was found under a bare pebble.

SEASONALITY. Generally, this species is present throughout the year, even if the huge assemblages were documented during winter and spring (Lombardo et al., 2020; present study).

REMARKS. During this study an "attack", provoked by a small unidentified "prosobranch", was observed on a $E$. pedata specimen. This last individual presented large part of the body severely dried out.

Genus Flabellina (McMurtrie, 1831

Flabellina affinis (Gmelin, 1791) (Fig. 10)

Morphology. This species possesses an elongated body, almost totally violet coloured (in various shades). The rhinophores present many annulations for almost their entire length, while the oral tentacles are smooth. The ends of all the cephalic tentacles are white coloured. The cerata are arranged in groups. Each of them comes from a stalk on the surface of the notum. Through the cerata is possible to note the 
digestive gland's branches. They can possess a colouration from light orange to dark red violet. The tips of the cerata are white.

ABUndANCE. From common to very common.

LOCATION AND DEPTH. This nudibranch was found in all the examined areas from 8 to $41.8 \mathrm{~m}$ of depth (Lombardo \& Marletta, 2020c; present study).

SUBSTRATES AND HABITATS. The main substrate on which $F$. affinis and its pink egg masses were found are the colonies of Eudendrium sp.. However, this nudibranch moves a lot (probably from an $\mathrm{Eu}$ dendrium $\mathrm{sp}$. colony to another). Consequently, this species can be encountered on many algal and animal substrates: Plocamium cartilagineum (Linnaeus) P. S. Dixon; Peyssonnelia sp.; F. rayssiae; Rhodymenia sp.; Eupogodon planus (C. Agardh) Kützing; Sphaerococcus coronopifolius Stackhouse; Sebdenia monardiana (Montagne) Berthold; filamentous red algae; mix of red and brown algae; $D$. dichotoma (also the egg masses); Z. tournefortii; H. filicina; C. cylindracea; Codium bursa (Olivi) C. Agardh; Paramuricea clavata (Risso, 1826) and C. crambe. Rarely, some specimens were observed on sandy substrates.
SEASONALITY. Flabellina affinis is a species that can be potentially present, in large numbers, in any season of the year (Lombardo \& Marletta, 2020c).

\section{Flabellina cavolini (Vérany, 1846) (Fig. 11)}

MoRPhOLOGY. This species presents a white coloured elongated body with azure hues. The rhinophores and the oral tentacles are smooth, and their distal halves are totally white coloured. On the head, in front of each rhinophore there is an evident violet blotch. The cerata present a transparent colouration through which it is possible to see the red digestive gland's branches. The tips of these are grey coloured. The cerata are arranged in groups, each of them comes from an evident stalk on the surface of the notum.

ABUNDANCE. Eighty-two (82) specimens were observed in the course of the present study, most of which in the sites of Santa Maria La Scala and Santa Tecla. This species can be considered as uncommon.

LOCATION AND DEPTH. Flabellina cavolini was documented in all the examined areas from 4 to 38 $\mathrm{m}$ of depth.
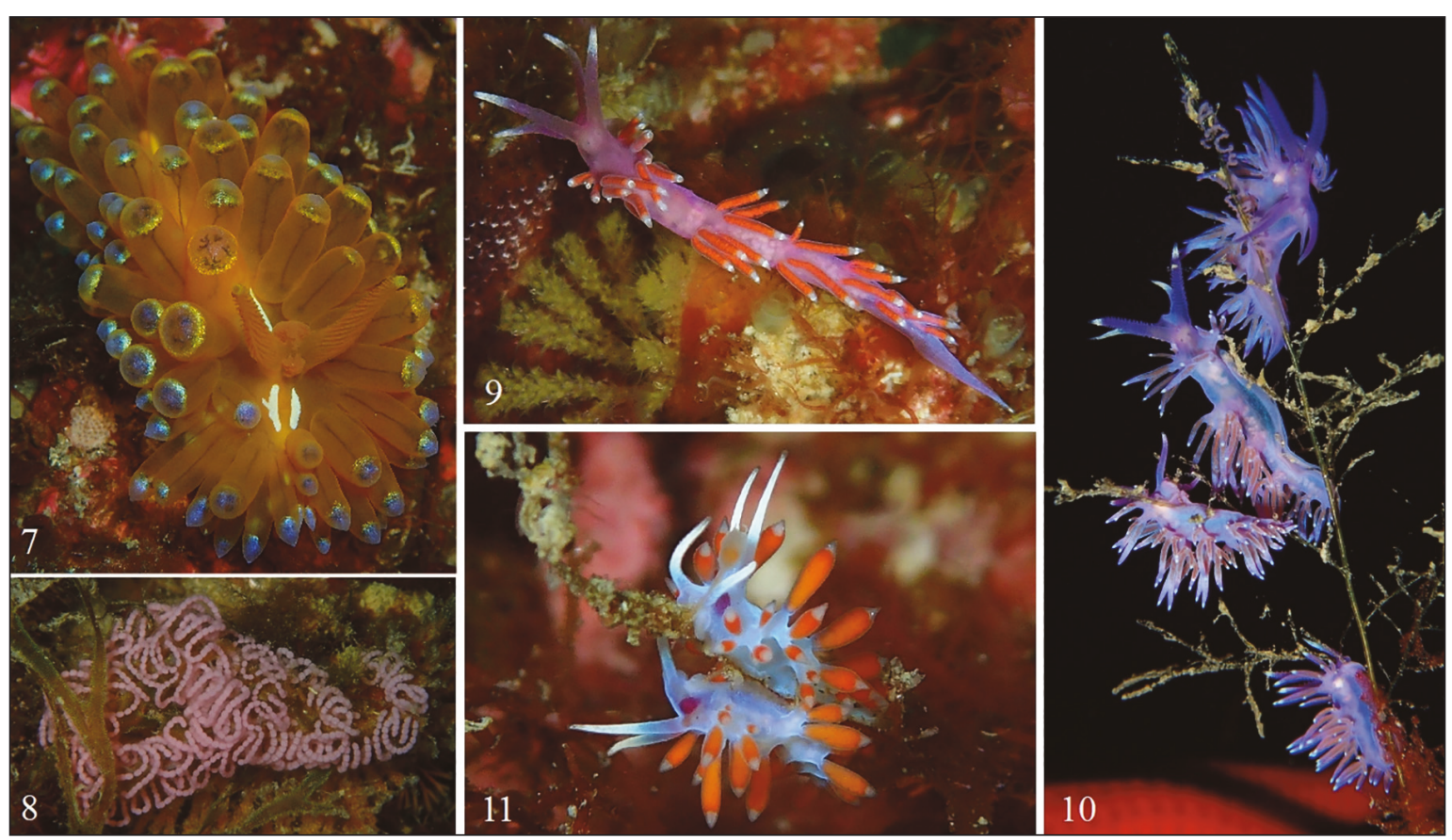

Figures 7-11: Janolidae and Flabellinidae. Fig. 7: Antiopella cristata. Fig. 8: A. cristata's egg mass. Fig. 9: Edmundsella pedata. Fig. 10: several Flabellina affinis specimens with an egg mass. Fig. 11: two Flabellina cavolini specimens (photos by A. Lombardo). 
SuBSTRATES AND HABITATS. The main substrate on which the specimens were typically found were the Eudendrium spp. colonies. Specifically, it was observed that $F$. cavolini is found, mainly, on the smallest and poorly branched colonies, upon which this species lay its egg masses (white coloured and with a loose ribbon shape). Moreover, this nudibranch was found on other substrates, especially algae like: Bonnemaisonia sp.; S. monardiana; $F$. rayssiae; Peyssonnelia sp.; Jania sp. surrounded by red and brown algae; mix of red algae with detritus; $D$. dichotoma; $D$. implexa and H. filicina.

SEASONALITY. Flabellina cavolini was found all year round. However, January, February, March and April were the months in which the majority of specimens were observed. The egg masses were documented in January, February, March, April, May, June, August and October. The mating activity was observed in January, March and May.

Genus Paraflabellina Korshunova, Martynov, Bakken, Evertsen, Fletcher, Mudianta, Saito, Lundin, Schrödl et Picton, 2017

Paraflabellina ischitana (Hirano et T.E. Thompson, 1990) (Fig. 12)

MORPHOLOGY. This nudibranch presents a violet body colouration, almost transparent. The rhinophores are annulated while, the oral tentacles possess a smooth tegument. The cerata are organized in dense groups, each of them stems from an evident peduncle. The tegument of each cerata presents a strong transparency, which makes perfectly visible the red-orange coloured digestive gland's branches. The tips of the cerata are white coloured. The cerata possess, generally, an elongated shape. Usually, through the head's tegument is possible to see the red coloured jaws.

ABUNDANCE. Eighty-five (85) specimens were found during this study, most of them in the sites of Santa Maria La Scala. This species can be considered as uncommon.

Location And DePTH. Paraflabellina ischitana was documented in all the examined sites from 10.3 to $38.8 \mathrm{~m}$ of depth.

SuBSTRATES AND HABITATS. This nudibranch was observed, almost always, on large and dense Eudendrium sp. colonies in small groups of 3-4 individuals with the white-orange ribbon shaped egg masses. Rarely, this species was documented on different substrates like: calcareous red algae; $S$. monardiana; $D$. dichotoma; $H$. filicina and the bryozoan M. truncata.
Seasonality. Paraflabellina ischitana can be present all year round. The egg masses were found in all months of the year except February and May.

\section{Familia CORYPHELLIDAE Bergh, 1889}

Genus Fjordia Korshunova, Martynov, Bakken, Evertsen, Fletcher, Mudianta, Saito, Lundin, Schrödl et Picton, 2017

Fjordia lineata (Lovén, 1846) (Fig. 13)

MorPhOLOGY. The body presents a grey-transparent colouration, through it, it is easily observable the animal's interior. The rhinophores and the oral tentacles are smooth. Each of the latter possesses a white line, along its entire length. These lines come together in front of the rhinophores, forming a single white line that extends longitudinally across the back to the tip of the tail. On each flank there is a white coloured line. The cerata are elongated in shape and arise directly from the notum. They are transparent-grey coloured, and, through them, it is possible to see the orange-brown coloured digestive gland's branches. The anterior surface of each cerata presents a white coloured line. Rarely, the surface of the cerata can present small white dots.

ABUNDANCE. Overall, 12 specimens were found during this study. Consequently, it can be considered from rare to uncommon.

LOCATION AND DEPTH. Fjordia lineata was found in all the examined sites from 7.1 and $34 \mathrm{~m}$ of depth.

SUBSTRATES AND HABITATS. This nudibranch was observed on different substrates: $F$. rayssiae; Peyssonnelia sp.; mix of filamentous red and brown algae; D. dichotoma; H. filicina; the bryozoan Schizoporella sp. and the sponge C. crambe.

SeAsonality. March, April and May.

Familia SAMLIDAE Korshunova, Martynov, Bakken, Evertsen, Fletcher, Mudianta, Saito, Lundin, Schrödl et Picton, 2017

Genus Luisella Korshunova, Martynov, Bakken, Evertsen, Fletcher, Mudianta, Saito, Lundin, Schrödl et Picton, 2017

Luisella babai (Schmekel, 1972) (Fig. 14)

MorPhOlOGY. This nudibranch presents the body grey-transparent coloured. The rhinophores are club-shaped and their tips have an orange col- 
ouration. The oral tentacles are much longer and large than the rhinophores. They have their distal half totally white coloured, while their proximal half are shaded in azure. Two azure lines start from the base of each oral tentacles. One borders the foot on each side of the body until the tail. The other, the most evident one, runs from each side of the head to the tail. This last line encounters on its way all the cerata stalks, colouring them with an azure shade. The distal half of each cerata possesses a yellow colouration that become orange near the tips. These last are grey coloured.

ABUNDANCE. 34 specimens were observed during this study, the majority of which in the site of Santa Maria La Scala. This species can be considered as uncommon.

LOCATION AND DEPTH. Luisella babai is presents in all the examined sites from 20 to $41.3 \mathrm{~m}$ of depth.

SubStRATES AND habitats. This species was found on the following substrates: calcareous red algae; S. monardiana; Peyssonnelia sp.; C. squamariae; Z. tournefortii; H. filicina; unidentified orange and yellow coloured sponges and the bryozoan M. truncata.
SeAsonality. Luisella babai was observed all year round. The reproductive activities were documented in June, July, August and October.

REMARKS. Almost always, the specimens were in pairs. Often, when a single specimen was found, there was always another individual in its immediate vicinity.

\section{Familia EUBRANCHIDAE Odhner, 1934}

Genus Amphorina Quatrefages, 1844

Amphorina farrani (Alder et Hancock, 1844) (Figs. 15-17)

MoRPhOlOGY. This species presents two different chromatic patterns. Almost all the encountered specimens possess a grey-transparent body colouration. The rhinophores and the oral tentacles are smooth. Their distal halves are orange or yellow coloured. Frequently, the body's surface (head and notum) has orange or yellow dots/blotches. The cerata are fully transparent and present a slightly swollen shape in the middle of their height. Their tips are orange or yellow coloured. Many specimens, together with the normal cerata above mentioned, possess some extremely swollen almost
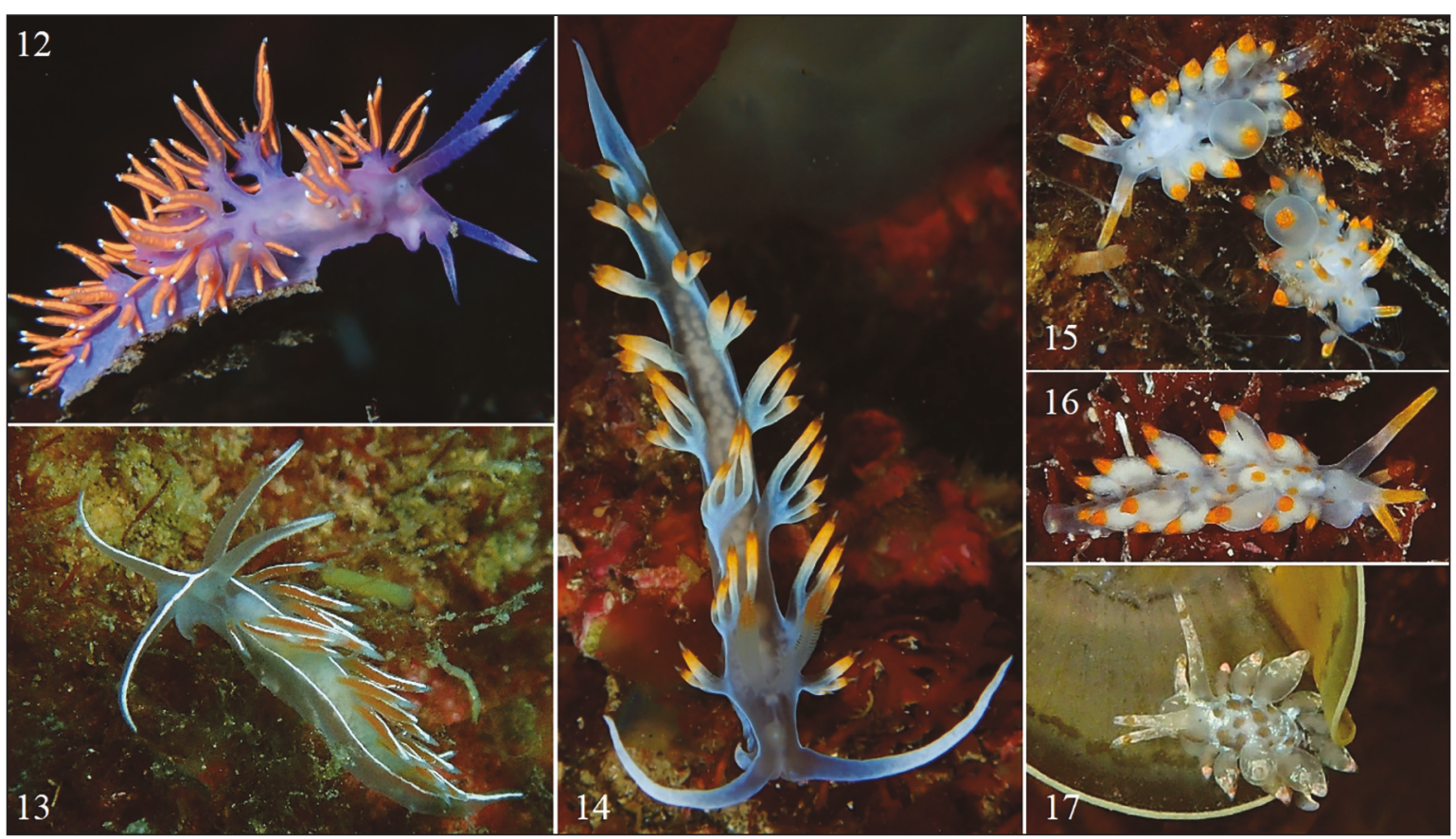

Figures 12-17: Flabellinidae, Coryphellidae, Samlidae and Eubranchidae. Fig. 12: Paraflabellina ischitana. Fig. 13: Fjordia lineata. Fig. 14: Luisella babai. Fig. 15: two Amphorina farrani specimens with spherical cerata. Fig. 16: A. farrani specimen with orange blotches. Fig. 17: A. farrani specimen with the second chromatic pattern (photos by A. Lombardo). 
spherical cerata. During this study, only one specimen with another chromatic pattern was observed. In this variant the body is grey-transparent coloured, and it is covered by scattered brown blotches. Together with these, there are many clusters of bright white-azure dots. Distally, the rhinophores and the oral tentacles present a brown coloured band. Moreover, they possess bright white dots along their entire surface. The cerata are transparent and, from their distal halves, they possess many clusters of small bright white dots. Apparently, the tips are pink shaded.

Abundance. Thirty-two (32) specimens were found during this study. This species can be considered as uncommon.

LOCATION AND DEPTH. Amphorina farrani was documented in all the examined areas from 3.9 to $18.4 \mathrm{~m}$ of depth.

SubStRATES AND HABITATS. This nudibranch was observed on several substrates like: filamentous red algae; F. rayssiae; Bonnemaisonia sp.; Pterocladiella capillacea (S. G. Gmelin) Santelices \& Hommersand covered by epiphytes; Jania sp. covered by cyanobacteria and diatoms; $D$. dichotoma; H. filicina; Z. tournefortii; Cladophora sp.; unidentified hydrozoan and the bryozoans Schizoporella sp. and Diplosolen sp. Only a specimen was found freely floating at a few metres from the bottom.

Seasonality. Amphorina farrani was documented in January, February, March, April, May, October and December. The breeding activity was observed in April.

REMARKS. Generally, the specimens were always individually found. Only on one occasion, in April 2019, an A. farrani's assemblage (10 specimens) was observed at $6.4 \mathrm{~m}$ of depth below a small shady rocky.

Genus Capellinia Trinchese, 1873

Capellinia doriae Trinchese, 1874 (Figs. 18-20)

MoRPhOlOGY. This species presents an elongated body with a grey-transparent colouration. Along the entire surface of the body there are green-brown and bright white blotches. At a closer look, on each side of the notum there are two green coloured line. The rhinophores and the oral tentacles are smooth. The formers are longer than the latter. The cephalic appendages possess the same stripe/blotches that there are on the body surface. The cerata have several protrusions, each of which has a white coloured dot on its tip.

ABundance. Only two specimens were found during this study. Consequently, this species can be considered as rare.

LOCATION AND DEPTH. The two specimens were documented in Santa Maria La Scala and in Santa Tecla at 9.1 and $3.9 \mathrm{~m}$ of depth respectively.

SubStRATES AND habitATS. One individual was found on Taonia sp. surrounded by red algae, while the other on Jania sp. covered by diatoms and cyanobacteria.

SEASONAlity. March and May.

Remarks. Capellinia doriae is extremely difficult to see in the field, due to its small size and colour pattern.

\section{Genus Eubranchus Forbes, 1838}

\section{Eubranchus tricolor Forbes, 1838 (Fig. 21)}

MORPHOLOGY. This species presents a characteristic blue-transparent body colouration. The rhinophores and the oral tentacles are smooth. The formers are longer than the latter. Distally, the cephalic appendices possess white shaded colouration. The cerata are longitudinally elongated and flattened in front-rear direction. They are bluetransparent coloured. Through them, it is possible to see the narrow cream-orange coloured digestive gland's branches. The tips of the cerata are white shaded.

ABUndANCE. Only two specimens were found during this study. Consequently, this species can be considered as rare.

LOCATION AND DEPTH. Eubranchus tricolor was documented in Santa Tecla and Catania at 9 and 6 $m$ of depth respectively.

SUBSTRATES AND HABITATS. This nudibranch was observed on a thallus of Griffithsia sp. surrounded by gravel and on Cladophora sp.

SeAsonality. February and March. 
Familia TRINCHESIIDAE F. Nordsieck, 1972

Genus Trinchesia H. von Ihering, 1879

Trinchesia caerulea (Montagu, 1804) (Fig. 22)

MoRPHOLOGY. This species has a grey-transparent body colouration, through which the interior parts are easily observable. The rhinophores and the oral tentacles are smooth and for most of their length they are light-yellow shaded. Even the tail is coloured in the same way. The cerata are small and slightly swollen. They have the base grey-transparent, most of their surface crayon-azure, the distal part yellow and the tip white or transparent coloured. In some specimens the basal part of the cerata is characterized by many cream-coloured dots. One specimen presents an evident spherical swelling in the distal part of one of the rhinophores.

ABUndDANCE. Twelve (12) specimens were found during this study. Consequently, this species can be considered from uncommon to rare.

LOCATION AND DEPTH. Trinchesia caerulea was documented in Santa Maria La Scala and Catania from 26 to $36.9 \mathrm{~m}$ depth.

SubStRATES AND Habitats. This nudibranch was found almost exclusively on Sertularella sp. colonies with its egg masses that are U shaped and white coloured. Sometimes T. caerulea was observed on $Z$. tournefortii and Rhodymenia sp. covered by detritus.

SEAsOnAlity. The animals were documented in February, March, April, May and August. The egg masses were found in April and August.

Remarks. See below in Trinchesia morrowae Korshunova et al., 2019.

Trinchesia cf. diljuvia Korshunova, Picton, Furfaro, Mariottini, Pontes, Prkić, Fletcher, Malmberg, Lundin et Martynov, 2019 (Fig. 23)

Morphology. The animal presented a body grey-transparent coloured. Along the entire anterior surface of the head and of the dorsum, there were many close white bright dots, almost forming a band. The rhinophores and the oral tentacles were smooth and most of their length was opalescent white coloured. This colouration was more evident on the rhinophores than on the oral tentacles. The cerata were transparent with a characteristic shape. Through them, the digestive gland's branches, with an evident brown colouration, can be observed.
From the distal part of the cerata and forward, many white bright dots (identical to those scattered on the body's surface) hide almost completely the brown branches, colouring the tips of opalescent white.

ABUndANCE. A specimen was found on $8^{\text {th }}$ of May 2020.

LOCATION AND DEPTH. The animal was observed in Santa Maria La Scala at $7.6 \mathrm{~m}$ of depth.

SUBSTRATES AND HABITATS. The nudibranch was on a thallus of $H$. scoparia.

SEAsonality. May.

Remarks. The encountered specimen corresponds with the description of T. diljuvia. In fact, the small size, the chromatic pattern, and the shape of the cerata match perfectly with those of the nudibranch described by Korshunova et al. (2019). If this specimen is a T. diljuvia, this report would represent the first Mediterranean record of this species. In fact, this nudibranch is known only for the Yalta region (Black Sea) (Korshunova et al., 2019).

Trinchesia foliata (Forbes et Goodsir, 1839) (Fig. 24)

MoRPHOLOGY. The body is grey coloured. Along its entire surface there are many white blotches arranged more or less neatly. On the head, it is possible to note two orange-brown coloured lines that widen behind the head and join behind the pericardium forming a rhomboid pattern. On each side of the body there is a line identical to the previous ones. Dorsally the head is white coloured, as well as the rhinophores and most of the oral tentacles. The cerata can possess an elongated or a barrel shape. For most of their proximal half, they are provided of white and black blotches. Under each tip, that is grey and narrower than the cerata, there is an orange-coloured band. Almost all the specimens have a stubby body, but rarely, elongated shaped specimens were observed.

ABUNDANCE. One-hundred and thirty-seven (137) specimens were found during this study. This species can be considered from common to uncommon.

LOCATION AND DEPTH. Trinchesia foliata was documented in all the examined sites from 4 to 26.6 $\mathrm{m}$ of depth.

SUBSTRATES AND HABITATS. This nudibranch was observed on different algal and animal substrates: filamentous red algae; Ceramium sp.; F. rayssiae; 


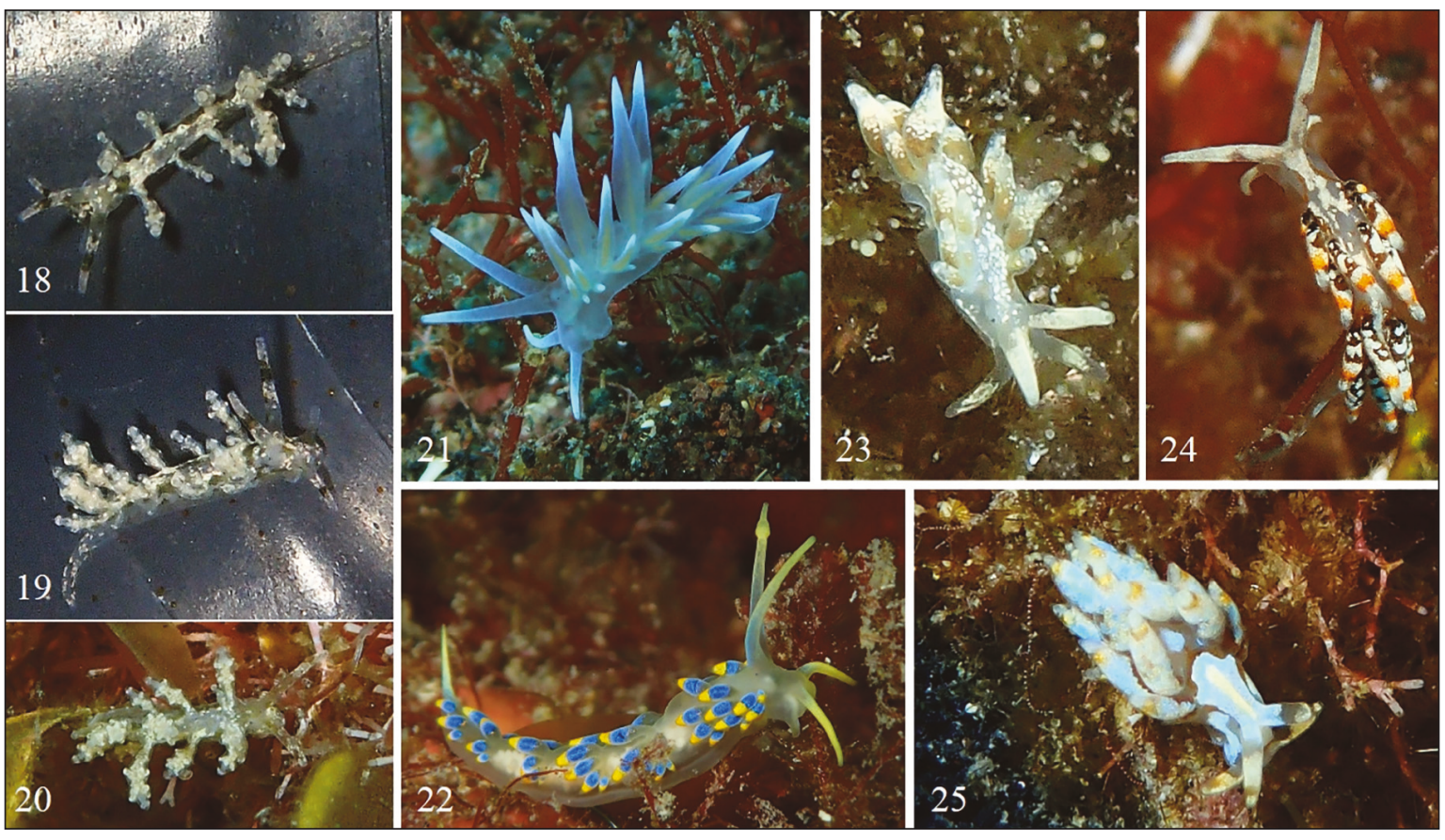

Figures 18-25: Eubranchidae and Trinchesiidae. Fig. 18: dorsal view of a Capellinia doriae specimen. Fig. 19: right-lateral view of the same. Fig. 20: another specimen on the substrate. Fig. 21: Eubranchus tricolor. Fig. 22: Trinchesia caerulea. Fig. 23: Trinchesia cf. diljuvia. Fig. 24: Trinchesia foliata. Fig. 25: azure Trinchesia genovae (photos by A. Lombardo).

Peyssonnelia sp.; Acrosorium ciliolatum (Harvey) Kylin; $D$. dichotoma; $D$. implexa covered by diatoms; H. scoparia; Z. tournefortii with hydrozoans; Valonia sp.; Crisularia plumosa (Pallas, 1766); Amathia verticillata (delle Chiaje, 1822); Eudendrium sp.; M. truncata and Petrosia (Petrosia) ficiformis (Poiret, 1789).

Seasonality. Trinchesia foliata was documented all year round. The reproductive activities were observed in May, August and October.

REMARKS. Generally, this small nudibranch is found among or under the thalli of abovementioned algae. Consequently, it is highly probable that $T$. $f_{O}$ liata's populations are more numerous than it seems.

Trinchesia genovae (O’Donoghue, 1926) (Figs. $25,26)$

Morphology. This species is present in two principal chromatic patterns, both of which have a grey coloured body; smooth rhinophores and oral tentacles that are coloured for most of their surface (see below) and with a brown coloured band on each rhinophore; barrel-shaped cerata, with the narrow tips grey coloured and with an or- ange ring under them; on the head and the surface of the pericardium area there are orange coloured lines that form a rhomboidal pattern and an evident longitudinal yellow coloured stripe within the latter. In the first chromatic pattern, the animal presents the head, cerata and the areas within the orange lines azure coloured. In the second type these areas are white with the exception of the cerata, that possess many close cream-coloured dots.

ABUNDANCE. Seventy-four (74) specimens were found during this study. This species can be considered as uncommon.

LOCATION AND DEPTH. This nudibranch is presents in all the examined sites from 4.6 to $37.2 \mathrm{~m}$ of depth.

SubStRATES AND habitATS. Trinchesia genovae was observed on the following substrates: calcareous red algae; Peyssonnelia sp.; L. lallemandii; $D$. dichotoma; Z. tournefortii; H. filicina; H. scoparia; Halimeda tuna (J. Ellis \& Solander) J. V. Lamouroux and on small unidentified tunicates.

SEASONALITY. This nudibranch was documented all year round. However, most of the specimens were encountered in March, April, May and June. 
REMARKS. As the previous species, T. genovae presents a strongly sciaphilous behaviour.

Trinchesia morrowae Korshunova, Picton, Furfaro, Mariottini, Pontes, Prkić, Fletcher, Malmberg, Lundin et Martynov, 2019 (Fig. 27)

MorPHOLOGY. This nudibranch presents a grey coloured body, sometimes slightly transparent. Along all the dorsal surface there is a white coloured stripe. It goes from the point of the tail to the anterior part of the head, where the stripe bifurcates colouring with white most of the rhinophores and the oral tentacles. The cephalic appendages possess the distal parts yellow coloured. The cerata are variously coloured. At their bases they are transparent (through which it is possible to note the blackish digestive gland's branches), becoming upwards black with yellow dots, yellow, crayon blue and white at their tips. Almost all the specimens possess a longitudinal white coloured line along each flank.

ABundance. Thirty-six (36) specimens were found during this study. This species can be considered as uncommon.

LOCATION AND DEPTH. This nudibranch was documented in all the examined areas from 2.9 to $29.2 \mathrm{~m}$ of depth.

SubSTRATES AND HABITATS. Trinchesia morrowae was observed on several substrates: Bonnemaisonia sp.; Peyssonnelia sp. covered by encrusting bryozoans; L. lallemandii; turfs of Jania sp. and Ceramium sp. covered by diatoms and cyanobacteria; H. filicina; H. scoparia; Cladophora sp.; D. disticha and Sertularella sp..

SEASONALITY. Trinchesia morrowae was documented all year round except in October.

REMARKS. This species seems to be typical of the first $10 \mathrm{~m}$ of depth. In fact, only two specimens under this depth were found. Along the central-eastern coast of Sicily, it would appear to be a clear ecological distinction between the two azure-species belonging to the "Trinchesia caerulea complex" (Korshunova et al., 2019), retrieved during this study. In fact, all $T$. caerulea's specimens were documented from 26 to $36.9 \mathrm{~m}$ of depth. Although both the species seem to have a sciaphilous behaviour, T. morrowae was found several times in well-lit environments and on several substrates. Instead, T. caerulea, was almost always observed on deep Sertularella sp. colonies.
Trinchesia ocellata Schmekel, 1966 (Fig. 28)

Morphology. This species presents a greygreenish transparent body colouration. Dorsally, from the tip of the head to the point of the tail, there is a white coloured line. In almost all the observed specimens, this line is discontinued. On each side of the head there is a narrow white line. The rhinophores and the oral tentacles are smooth. They, for almost their entire length, are white coloured. The cerata have an elongated shape and, through them, it is possible to see the orange-coloured digestive gland's branches. The distal part of each cerata possesses many white dots, which come together to form spots. The tips are dark violet coloured.

Abundance. Ten (10) specimens were found during this study. T. ocellata can be considered from rare to uncommon.

LOCATION AND DEPTH. This nudibranch was documented in all the examined areas from 17 to $36 \mathrm{~m}$ of depth.

Substrates And habitats. Principally, T. ocellata was observed on Eudendrium sp. colonies with its egg masses (loose ribbon-shaped white coloured). Moreover, this species was found on: H. filicina; D. implexa and Sertularella $\mathrm{sp}$.

Seasonality. March, April and May.

REMARKS. The reproductive activities were observed in March, while the egg masses were found in March and April.

\section{Familia EMBLETONIIDAE Pruvot-Fol, 1954}

Genus Embletonia Alder et Hancock, 1851

Embletonia pulchra (Alder et Hancock, 1844)

(Fig. 29)

MORPHOLOGY. This species presents an elongated and dorso-ventrally flattened body. It is white coloured, except for the sides of the head, the rhinophores' posterior surface and the majority of the oral veil, which are all grey-transparent coloured. The cerata are sausage-shaped and cream coloured. The tips are transparent. One specimen had several white dots on cerata, on the sides of the head and on the oral veil.

ABUNDANCE. Only four specimens were found during this study. E. pulchra can be considered as a rare species. 
LOCATION AND DEPTH. This nudibranch was encountered in all the examined areas from 6 to $10 \mathrm{~m}$ of depth.

SUBSTRATES AND HABITATS. Embletonia pulchra's specimens were observed on volcanic gravel, under pebbles with serpulids and diatoms in strict contact with sediment and detritus.

\section{SEASONALITY. May and June.}

REMARKs. The animals, once exposed to light, were frantically trying to reach niches and small cracks in the pebbles on which they stood. Nevertheless, a specimen was found creeping on volcanic gravel in a well-lit area. Moreover, another specimen, as soon as he was touched the author, lost several cerata.

Familia FACELINIDAE Bergh, 1889

Genus Caloria Trinchese, 1888

Caloria elegans (Alder et Hancock, 1845) (Fig. 30)

MORPHOLOGY. The body is grey-transparent coloured. An opalescent white line is present on the distal and inner rhinophores' and oral tentacles' sur- face. It is also present on the dorsal surface of the tail. The cerata are transparent and through them, it is possible to see the orange-cream coloured digestive gland's branches. Moreover, the cerata are distally black coloured, while the tips are white.

ABundance. Only two specimens were found during this study. C. elegans can be considered as a rare species.

LOCATION AND DEPTH. The specimens were documented in Santa Maria La Scala and Catania at 21.3 and 27.8 metri of depth respectively.

SubStRATES AND Habitats. The animals were observed on the red algae Rhodymenia sp. and $F$. rayssiae.

Seasonality. October and November.

Genus Cratena Bergh, 1864

Cratena peregrina (Gmelin, 1791) (Fig. 31)

MORPHOLOGY. This species presents an elongated white-grey coloured body. The rhinophores and the oral tentacles are smooth. The formers are transparent with orange tips, while the latter are principally white coloured. In front of each rhinophore, there is

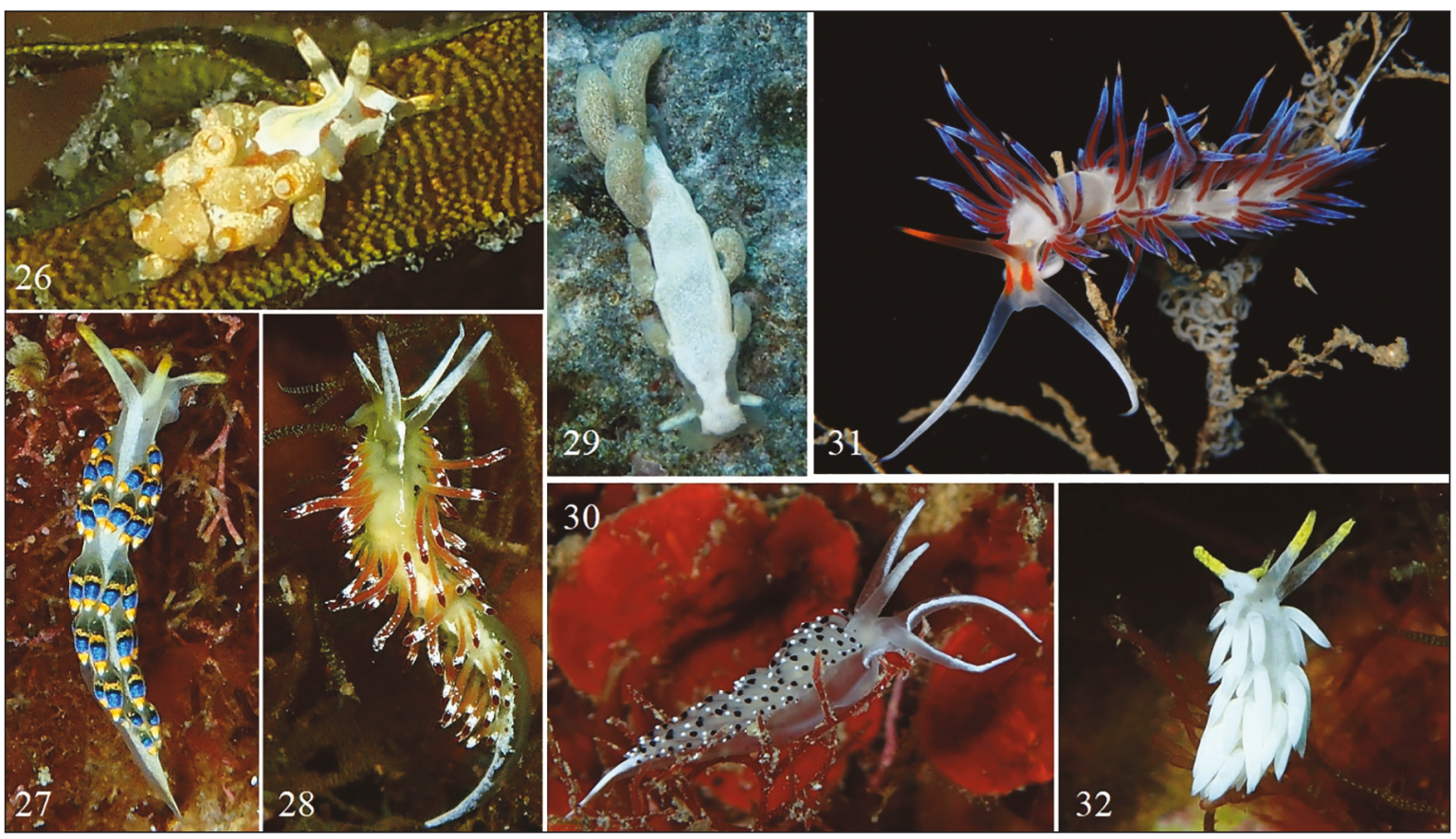

Figures 26-32: Trinchesiidae, Embletoniidae and Facelinidae. Fig. 26: white-cream Trinchesia genovae. Fig. 27: Trinchesia morrowae. Fig. 28: Trinchesia ocellata. Fig. 29: Embletonia pulchra. Fig. 30: Caloria elegans. Fig. 31: Cratena peregrina. Fig. 32: Dicata odhneri. (photos by A. Lombardo). 
an evident longitudinally elongated orange blotch. The cerata, for most of their length, are transparent. Through them, it is possible to note the red-orange digestive gland's branches. Distally the cerata possess a blue-electric colouration. The tips are pointed and white. The dorsal tail's surface is white.

ABUNDANCE. From common to very common.

LOCATION AND DEPTH. Cratena peregrina was documented in all the examined areas from 3.9 to $40.5 \mathrm{~m}$ of depth.

Substrates AND habitats. Principally, the majority $C$. peregrina's specimens were found on $E u$ dendrium sp. colonies (also the egg masses) and on turfs of Jania sp. covered by diatoms and cyanobacteria. Moreover, this nudibranch was observed on several substrates like filamentous red algae plots; mix of red algae and detritus; Bonnemaisonia sp.; D. dichotoma (also the egg masses); Z. tournefortii (also the egg masses); H. scoparia; Cladophora sp. (also the egg masses); C. bursa; D. disticha and M. truncata.

Seasonality. Cratena peregrina is potentially present in large numbers all year round (Lombardo \& Marletta, 2020c; present study).

REMARKS. From 2020 until today, the trend between C. peregrina and F. affinis showed by Lombardo and Marletta (2020c) would appear to have been overturned. In fact, in this period was documented a high number of $C$. peregrina's specimens in all the examined areas. Instead, the $F$. affinis specimens' number would seem to have dropped dramatically. For example, in a single dive, more than 150 C. peregrina's specimens were observed in Santa Maria La Scala. Moreover, many specimens were documented above $10 \mathrm{~m}$ of depth, in well-lit environments rich of turfs of Jania sp. Probably, these specimens were in search of small hydrozoans to feed on.

\section{Genus Dicata Schmekel, 1967}

Dicata odhneri Schmekel, 1967 (Fig. 32)

MORPHOLOGY. This species has a white coloured body. The rhinophores and the oral tentacles are smooth. The formers are white, while their distal parts are lemon-yellow coloured. The latter are almost entirely yellow lemon, with the exception of the insertion zones with the head. The cerata are elongated and white coloured.
ABundance. Seventy-seven (77) specimens were found during this study. This species can be considered as uncommon.

LOCATION AND DEPTH. Dicata odhneri was documented in all the examined areas from 5 to $32 \mathrm{~m}$ of depth.

SUBSTRATES AND HABITATS. This nudibranch was observed on several substrates: D. implexa; Taonia sp.; H. filicina covered by diatoms; F. rayssiae; Peyssonnelia sp.; Asparagopsis sp.; Lomentaria sp.; Jania adhaerens J. V. Lamouroux; monosiphonous red filamentous algae; $C$. bursa and on an unidentified solitary hydrozoan.

SEASOnAlity. Dicata odhneri is presents all year round except in January.

REMARKs. Although D. odhneri has a striking colouring, it is not an easily observable species. In fact, often it was found among algae or in crevices. Consequently, this species can be considered sciaphilous. If touched, it tends to erect cerata in a hedgehog-shape and change direction, often wading through algae.

\section{Genus Facelina Alder et Hancock, 1855}

Facelina annulicornis (Chamisso et Eysenhardt, 1821) (Fig. 33)

MORPHOLOGY. This nudibranch presents a greytransparent coloured body, sometimes with evident black shades. Along the entire body's surface there are many golden dots (also on the rhinophores, oral tentacles and cerata). The rhinophores are annulated and, for most of their length, they have a grey-transparent colouration. The tips are white-cream coloured, while the part below them is brown, almost blackish. The oral tentacles are smooth and greytransparent coloured for most of their length. The distal parts possess close white-cream-coloured blotches/dots.

The cerata are transparent and through them it is possible to see the orange-brown digestive gland's branches. The tips are grey coloured. The entire surface of cerata is sprinkled with golden dots. In the smaller individuals, the dots, that are scattered along the body's surface, are huge and more sprinkled between them. In these animals, a general blackish body colouration prevails. The cerata possess, along their entire posterior surface, a cream colouration. 
ABUNDANCE. Twelve (12) specimens were found during this study. This species can be considered from rare to uncommon.

LOCATION AND DEPTH. Facelina annulicornis was documented in all the examined areas from 4.1 to $19.6 \mathrm{~m}$ of depth.

SubStRATES AND Habitats. This species was observed on several substrates: mix of turf red algae; Peyssonnelia sp.; Jania sp. among filamentous red and brown algae; H. filicina; under rock and pebbles on which there were serpulids, solitary hydrozoans and bryozoans (like Schizoporella sp.).

Seasonality. February, March, June, July and November.

Facelina rubrovittata (Costa A., 1866) (Fig. 34)

MORPHOLOGY. This species presents a greyish body colouration, occasionally it can be slightly transparent. Along the body's surface there are many longitudinal red-orange blotches (sometimes these are bordered with white) which form five discontinuous or continuous lines. Dorsally, from the point of the tail to the tip of the head there is the first line. Normally, this is continuous along the head's surface but became discontinuous behind the rhinophores. It subdivided in two lines on the snout, forming a distinctive pattern. On each body's flank, from the head to the tail, there are two longitudinal discontinuous lines that are parallel between each other. The point of the tail is opalescent white coloured. Generally, the rhinophores (grey in colour) are annulated in their white cream-coloured distal parts. Some specimens have the annulations so far apart that the distal halves of the rhinophores can present bulges. In the smaller individuals the rhinophores are smooth. The oral tentacles are smooth and grey coloured. Their distal halves are white cream. Some specimens have many opalescent white blotches on the oral tentacles' surface. The cerata, hook-shaped, are grey-transparent with azure shades and, through them, it is possible to observe the red coloured digestive gland's branches. The tips are white coloured.

ABUNDANCE. Eighty-three (83) specimens were found during this study. F. rubrovittata can be considered as an uncommon species.

LOCATION AND DEPTH. This nudibranch was documented in all the examined areas from 4 to $32 \mathrm{~m}$ of depth.
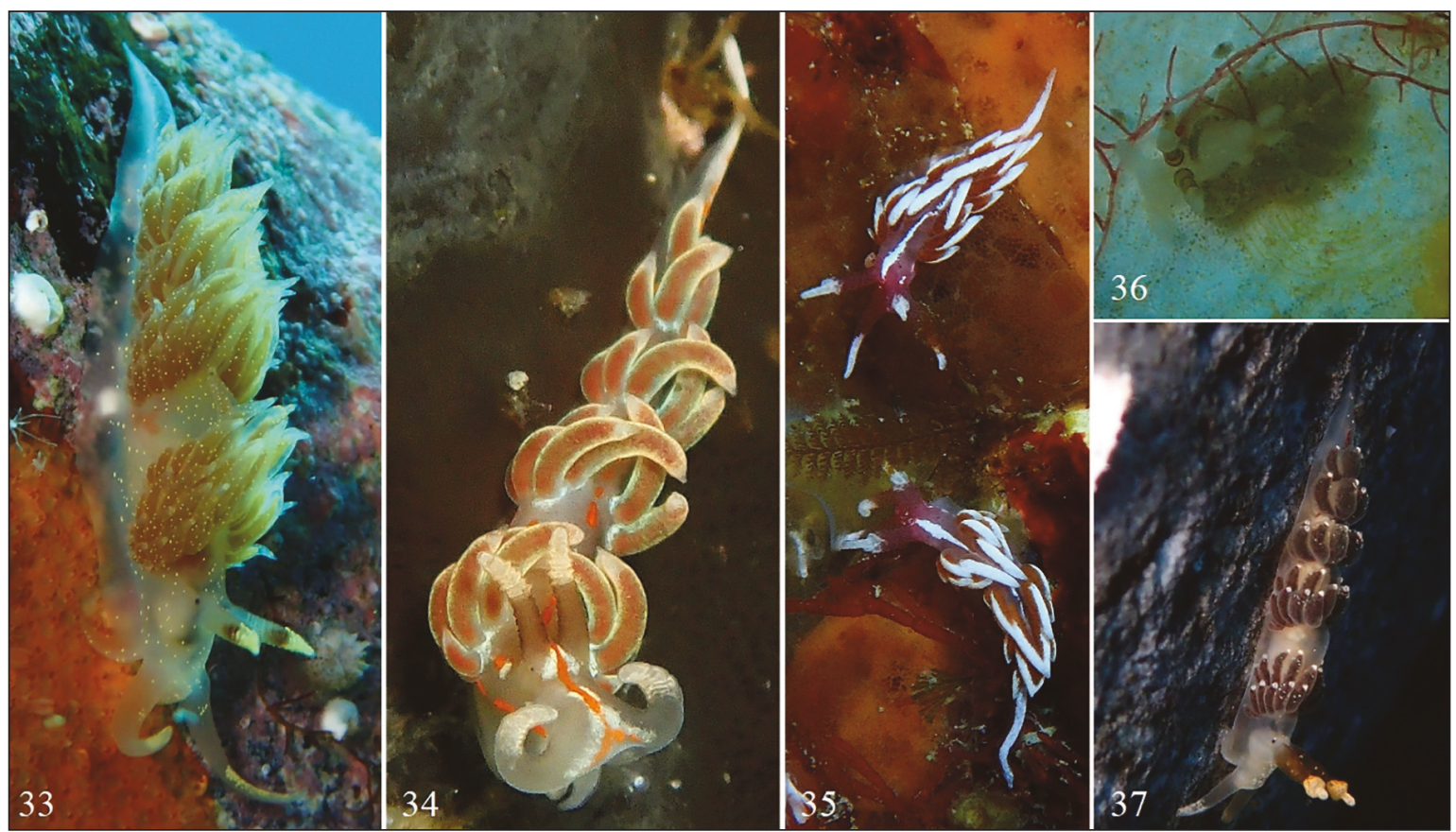

Figures 33-37: Facelinidae. Fig. 33: Facelina annulicornis. Fig. 34: Facelina rubrovittata. Fig. 35: two Facelinopsis marioni specimens. Fig. 36: a Favorinus branchialis specimen on Bosellia mimetica's egg masses. Fig. 37: right-lateral view of a F. branchialis specimen. (photos by A. Lombardo). 
SubSTRATES AND HABITATS. Facelina rubrovittata was observed on several substrates: mix of filamentous red algae; Peyssonnelia sp.; F. rayssiae; Griffithsia sp.; H. filicina; H. scoparia; D. dichotoma; P. crassum; P. ficiformis; Cacospongia sp. and small solitary hydrozoans.

Seasonality. This species can be present all year round.

REMARKS. Some individuals were observed while, apparently, preyed small solitary hydrozoans. When the nudibranchs came across one, first explored it with the oral tentacles and then encircled the small axis with the propodial tentacles, completely surrounding the polyp with the snout and keeping the oral tentacles strongly folded back.

Genus Facelinopsis Pruvot-Fol, 1954

Facelinopsis marioni (Vayssière, 1888) (Fig. 35)

MoRPhOlOGY. This nudibranch presents a violet-pink coloured body. The rhinophores proximally are lamellated, while in their distal part are smooth as the oral tentacles. The cephalic appendages have the same body colouration, except the distal parts that are white coloured. On the head there are several white dots, that, depending on the individual, can be more or less numerous. Dorsally, there is an evident white line that goes from the area between the rhinophores to the point of the tail. On each flank there are small longitudinal white dots, which form a very discontinuous line from the sides of the head to the tail. The cerata possess an evident white colouration on their external side and in the tips, while in the internal side they are brown coloured.

ABundance. One-hundred and two (102) specimens were found during this study. F. marioni can be considered as an uncommon species.

LOCATION AND DEPTH. This nudibranch was documented in all the examined areas from 3 to $27.9 \mathrm{~m}$ of depth.

SUBSTRATES AND HABITATS. The animals were observed on several substrates: F. rayssiae; Peyssonnelia sp.; Ceramium sp.; Jania sp.; Griffithsia sp.; Bonnemaisonia sp.; Rhodymenia sp.; calcareous red algae; H. filicina; D. dichotoma; D. implexa; Z. tournefortii; Cladophora sp. and C. crambe.

Seasonality. Facelinopsis marioni can be present all year round.
Remarks. Almost all the specimens were observed from 3 to $10 \mathrm{~m}$ of depth on rock walls covered by sciaphilous organisms and were often hidden by them.

Genus Favorinus M.E. Gray, 1850

Favorinus branchialis (Rathke, 1806) (Figs. 36, 37)

MoRPHOLOGY. This species has a grey-transparent body colouration. A huge opalescent white stripe can be present in front of the head. The oral tentacles are short and smooth, with their distal parts opalescent white in colour. The rhinophores may have spherical bulges at the base. Each rhinophore presents the distal part smooth and beneath it there is an evident cup-shaped swelling. Generally, the rhinophores are, from the base to the distal swellings, brown coloured while they are, from these latter to the tips, opalescent white coloured. The cerata are transparent and sometimes, along the entire body's surface can be present tiny opalescent white dots. The digestive gland's colouration varies according to the diet. Individuals with red, orange, white, cream, and dark brown digestive gland's branches were observed. The tip of each cerata is opalescent white coloured.

ABUndANCE. Nineteen (19) specimens were found during this study. F. branchialis can be considered as uncommon.

LOCATION AND DEPTH. This nudibranch was documented in all the examined areas from 4.5 to 37.4 $\mathrm{m}$ of depth.

SubStRATES AND HABITATS. Favorinus branchialis was observed on different substrates: egg masses of Dendrodoris limbata (Cuvier, 1804), of Dondice banyulensis Portmann \& Sandmeier, 1960, of Bosellia mimetica Trinchese, 1891; and H. scoparia; Peyssonnelia sp.; S. monardiana; H. tuna and beneath rocks.

Seasonality. March, April, May, June, July, August, September and November.

REMARKS. Its small size and the fact that it takes on almost the same colouring as the eggs on which it lives, and feeds make $F$. branchialis a very difficult species to find. Consequently, it is very likely that this species is much more common than it seems. 
Familia MYRRHINIDAE Bergh, 1905

Genus Dondice Er. Marcus, 1958

Dondice banyulensis Portmann et Sandmeier, 1960 (Fig. 38)

MoRPHOLOGY. This species has an orangetransparent body colouration. The rhinophores are annulated and of the same colour as the body. The oral tentacles, longer and wider than the former, are orange coloured near the head and white azure from the distal parts forwards. Two lines, whiteazure coloured, run from each oral tentacle. One goes to the centre of the snout, instead the other goes on each side of the head. The first ones, joining on the snout, form a single line that dorsally run from the head to the point of the tail. Each of the others forms a line on its respective side of the body that expands longitudinally to the tip of the tail, meeting in its path the bases of each group of cerata. These last are elongated in shape and strongly clustered together. Each ceratal cluster seems a flame. The cerata are transparent and the digestive gland's branches possess an orangecream colouration. The tips are red coloured. The edge of the foot is azure shaded. The red coloured jaws are easily observable through the head's tegument.

Abundance. Dondice banyulensis is a species whose occurrence is generally common-uncommon in the sites of Santa Maria La Scala. In the other sites it can be considered as rare (Lombardo \& Marletta, 2021b).

LOCATION AND DEPTH. This nudibranch was documented in all the examined areas from 5.8 to 40.5 $\mathrm{m}$ of depth.

SubStrates AND habitats. Dondice banyulensis was observed on several substrates: Eudendrium spp. (also the egg masses); P. clavata (also the egg masses); M. truncata; $H$. scoparia; $Z$. tournefortii (also the egg masses); S. monardiana (also the egg masses) (Lombardo \& Marletta, 2021b). Recently, small individuals were found on turfs of Jania sp. covered by diatoms and cyanobacteria; on Sertularella $\mathrm{sp}$. and S. sanguinea (present study).

Seasonality. This species can be present all year round (Lombardo \& Marletta, 2021b).

REMARKS. See Lombardo \& Marletta (2021b).
Dondice trainitoi Furfaro et Mariottini, 2020 (Fig. 39)

MORPHOLOGY. This species presents a transparent body colouration with bright blue shades. Along the body's surface there are three opalescent white-azurecoloured lines, that run from the head to the tail. The first line is formed by the union of the oral tentacles' lines, which by joining in front of the head, create a single dorsal line that run until the tail. The remaining two lines are each on each flank of the body. The rhinophores are annulated and transparent, except on the distal parts that have a cream-coloured band. The oral tentacles are smooth. The cerata are elongated in shape and through them, the brown coloured digestive gland's branches can be noted. The tips are white with a small yellowish area. The edge of the foot possesses many bright white-azure dots forming a stripe.

ABUNDANCE. Only one individual was found on $11^{\text {th }}$ of July 2017 (Gerovasileiou et al., 2020).

LOCATION AND DEPTH. The animal was documented in Santa Maria La Scala at $20 \mathrm{~m}$ of depth (Gerovasileiou et al., 2020).

SubSTRATES AND HABITATS. The specimen was observed on H. filicina thallus covered by epiphytes.

Genus Godiva Macnae, 1954

Godiva quadricolor (Barnard, 1927) (Fig. 40)

MoRPHOLOGY. This species presents a mainly white coloured body, with transparent areas. The head has an orange colouration. The rhinophores are wrinkled and dark orange coloured for most of their length. The distal parts are cream coloured. An azure band is present just above the base of each rhinophores. An evident azure stripe goes from each side of the head to the oral tentacles' base. These last are white coloured in their distal parts and orange white at the bases. The numerous and grouped cerata are hidden the back of the animal. The cerata present a particular chromatic pattern, that from the base towards the tips is repeated in this way: blue, brown, orange, brown, blue, etc. The tips are white-cream coloured.

ABUNDANCE. The only one individual was found on $23^{\text {rd }}$ of November 2018 (Lombardo \& Marletta, 2019).

LOCATION AND DEPTH. It was documented in Santa Maria La Scala at $7 \mathrm{~m}$ of depth (Lombardo \& Marletta, 2019). 


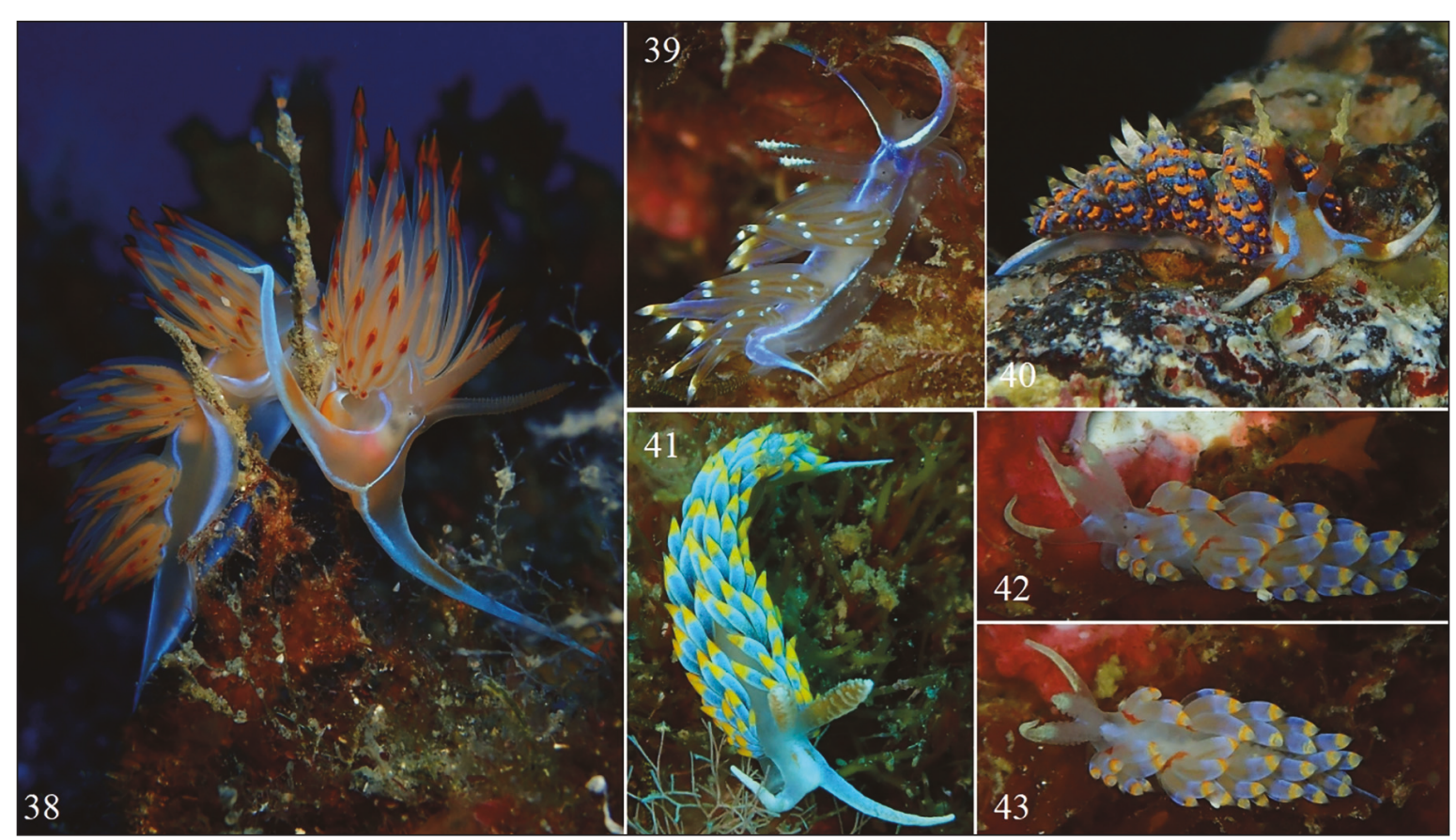

Figures 38-43: Myrrhinidae and Aeolidiidae. Fig. 38: Dondice banyulensis. Fig. 39: Dondice trainitoi. Fig. 40: Godiva quadricolor. Fig. 41: Berghia coerulescens. Fig. 42: left-lateral view of Berghia sp.. Fig. 43: dorsal view of the specimen (photos by A. Lombardo).

SubStRATES AND habitats. The specimen was observed beneath a rock (Lombardo \& Marletta, 2019).

REMARKs. See Lombardo \& Marletta (2019).

\section{Familia AEOLIDIIDAE Gray, 1827}

Genus Berghia Trinchese, 1877

Berghia coerulescens (Laurillard, 1832) (Fig. 41)

MoRPhOlOGY. This species has a white-almost azure body colouration. The rhinophores, cream coloured, are club shaped and present a lamellated anterior surface, while the posterior one is pustulose. The oral tentacles are longer than the rhinophores and possess a smooth surface of the same colour of the body. Generally, a more or less evident orange blotch is present in front of each rhinophore. Some specimens, encountered during this study, lacked these blotches. The cerata tend to hide most of the animal body. They are elongated and azure for most of their surface, instead they are yellow distally. The tips are white-transparent coloured. Usually, the tail is opalescent azure coloured.
ABUNDANCE. Fourteen (14) specimens were found during this study. This species can be considered from rare to uncommon.

LOCATION AND DEPTH. Berghia coerulescens was documented in all the examined areas from 8.1 to $36 \mathrm{~m}$ of depth.

SubSTRATES AND HABITATS. This nudibranch was observed on different substrates: turfs of Jania sp. and $F$. rayssiae covered by diatoms and cyanobacteria; mix of filamentous red algae; H. scoparia; $D$. dichotoma and $D$. implexa. Almost always, this species was found in open environments.

Seasonality. February, March, April, May, June and September.

REMARKS. One individual was observed while attacking a small actinia identified as Bunodeopsis cf. strumosa Andrès, 1881, which was on an entanglement of $D$. implexa thalli.

\section{Berghia sp. (Figs. 42, 43)}

Morphology. The found specimen presented a grey-transparent body colouration. The rhinophores and the oral tentacles had their distal halves yellow- 
cream coloured, while the proximal ones of the same colour of the body. The former seemed to be lamellated at the front. Instead, the latter were fully smooth. An azure-coloured stripe ran from the snout to the point of the tail. A red line was present at the base of the firsts two ceratal clusters. The cerata were greycream transparent coloured for most of their length. Distally they were azure shaded with a yellow-orange coloured ring. The tips were white transparent in colouration. Through the cerata, the narrow brown coloured digestive gland's branches could be noted.

ABUNDANCE. Only an individual was found during this study.

LOCATION AND DEPTH. The animal was documented in Santa Maria La Scala, on $7^{\text {th }}$ April 2018 at $36.1 \mathrm{~m}$ of depth.

SubSTRATES AND HABITATS. The specimen was observed on a Halymenia sp. thallus.

REMARKS. The individual described in this study presented an external morphology similar to three different species of the genus Berghia Trinchese, 1877: B. marinae Carmona, Pola, Gosliner \& Cervera, 2014; B. columbina (Garcia-Gomez \& T. E. Thompson, 1990) and B. rissodominguezi Muniain \& Ortea, 1999. Consequently, it was not possible to determine with certainty this specimen.

\section{Berghia verrucicornis (A. Costa, 1867) (Fig. 44)}

MORPHOLOGY. This species has a grey-transparent body colouration. The rhinophores are pustulosis and orange coloured, with the exception of the smooth and white coloured tips. The oral tentacles are long and smooth. They are, for most of their length, white coloured. An evident orange triangular blotch is present in front of each rhinophore. Behind the head, there is a huge orange blotch elongated in longitudinal sense. An identical one is present behind the last one. The cerata are greytransparent coloured.

Their distal parts are orange and the tips are grey-transparent in colouration. Through the cerata it is possible to note the evident brown digestive gland's branches.

ABUNDANCE. Only two specimens were found during this study. This species can be considered as rare.

LOCATION AND DEPTH. The animals were documented in Santa Maria La Scala and Catania, at 3.4 and $4.8 \mathrm{~m}$ of depth respectively.
SubSTRATES AND HABITATS. The specimen found in Santa Maria La Scala was observed on a H. scoparia thallus, instead that of Catania beneath a pebble covered by detritus.

SEAsonality. July and September.

Genus Limenandra Haefelfinger et Stamm, 1958

Limenandra nodosa Haefelfinger et Stamm, 1958 (Figs. 45, 46)

MorPHOLOGY. This nudibranch presents an elongated body principally green-brown coloured. Along the entire dorsal surface of the body there are peculiar circular marks. Each of them is made by a huge white circular blotch that is edged by two circles. The external one is yellow coloured while the internal one is red in colouration. Moreover, along the entire back there are, in an alternate way, small pustules that surrounded the circular blotches. The cerata are very characteristics. The smaller ones are almost always curved inwards, while the bigger ones are extended outwards. The latter seems like wings. Several white dots are scattered along the entire body surface. The rhinophores possess many papillae, mostly on their posterior surface. The oral tentacles are smooth. The cephalic appendages are green-brown coloured with several scattered white dots.

ABUNDANCE. Eight (8) specimens were found during this study. This species can be considered as rare.

LOCATION AND DEPTH. Limenandra nodosa was documented in Santa Maria La Scala and Santa Tecla from 3.1 and $17 \mathrm{~m}$ of depth.

Substrates AND Habitats. Principally, this species was observed on or among $H$. scoparia thalli. Moreover, it was documented on: H. filicina; Jania sp. with filamentous red algae covered by diatoms and cyanobacteria; Spyridia filamentosa (Wulfen) Harvey and Bonnemaisonia sp.

Seasonality. February, August and September.

REMARKS. Probably, Limenandra nodosa is one of the most cryptic cladobranchs of the studied areas. Generally, this nudibranch hires an elongated-shape body that, at a superficial glance, may resemble a small polychaete. In fact, the circular blotches, arranged all over the notum of this species, produce a disruptive effect which confounds the observer, giving the mollusc a metameric appearance. Consequently, it is probable that this nudibranch is more common than reported. 

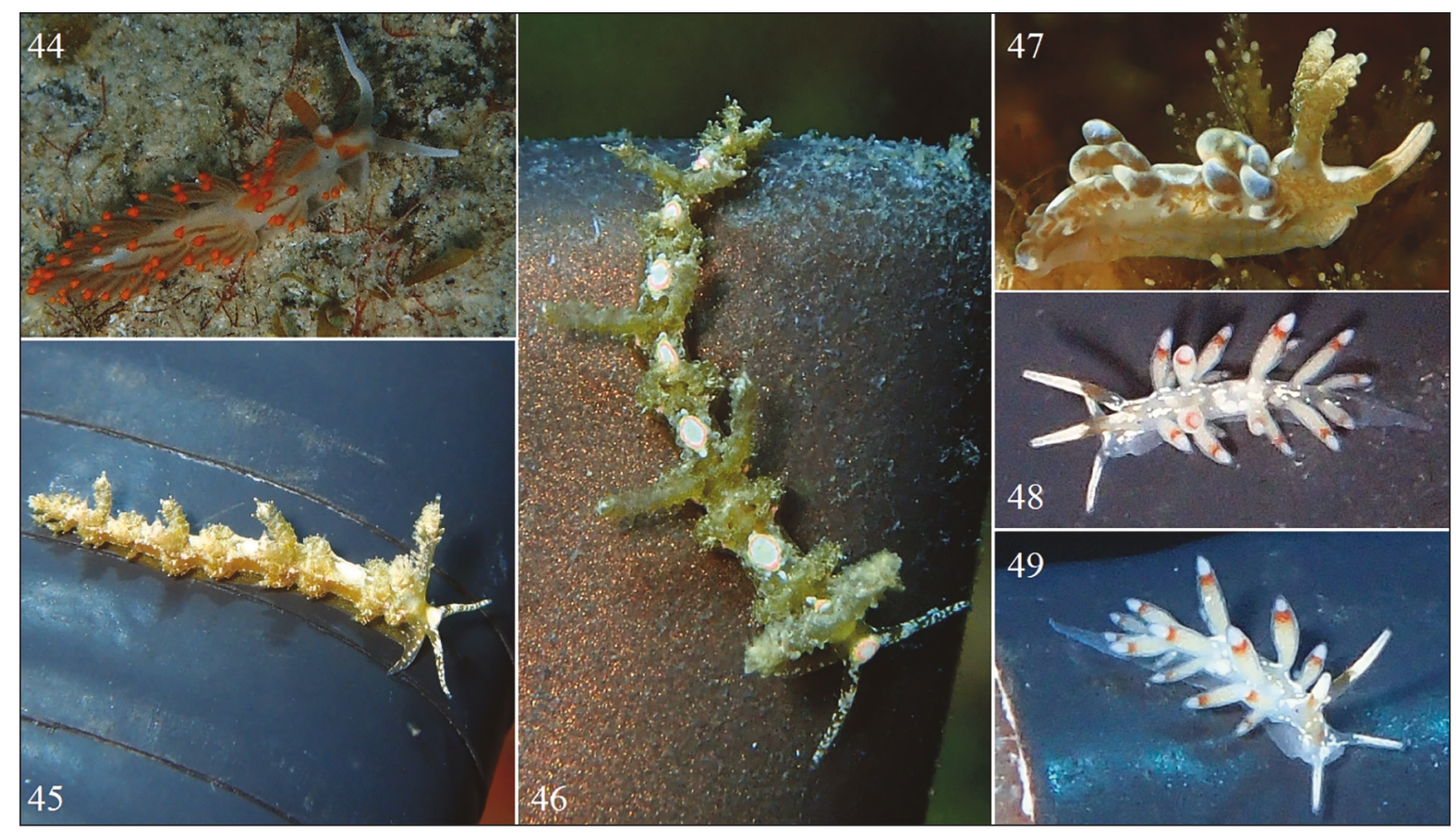

Figures 44-49: Aeolidiidae and Incertae sedis. Fig. 44: Berghia verrucicornis. Fig. 45: right-later view of a Limenandra nodosa specimen. Fig. 46: dorsal view of the same specimen. Fig. 47: Spurilla neapolitana. Fig. 48: left-lateral view of Eolid sp. 1. Fig. 49: right antero-lateral view of the same (photos by A. Lombardo).

Genus Spurilla Bergh, 1864

Spurilla neapolitana (Delle Chiaje, 1841) (Fig. 47)

MORPHOLOGY. This species has a grey-transparent body through them it is possible to note the numerous brown digestive gland's ramification. These branches also reach the rhinophores and the oral tentacles. The cephalic appendages are of the same colour of the body with their distal parts white-cream coloured. The rhinophores are distally lamellated, instead the oral tentacles are smooth. Dorsally there are, from the snout to the point of the tail, several white-azure coloured circular-ellipsoidal blotches, which can form a single longitudinal stripe or remain solitary. The cerata are curved inwards and transparent with superficial white-azure shades.

ABundance. Thirty-two (32) specimens were found during this study. S. neapolitana can be considered as an uncommon species.

LOCATION AND DEPTH. This nudibranch was documented in all the examined areas from 5 to $24.4 \mathrm{~m}$ of depth.

SuBSTRATES AND HABITATS. Spurilla neapolitana was observed on several substrates: turfs of Jania sp. covered by diatoms and cyanobacteria; filamentous red algae; Peyssonnelia sp.; H. scoparia; H. filicina covered by detritus and beneath naked pebbles.

Seasonality. This species was documented all year round, except in April.

REMARKS. Almost always, the specimens were observed on open and well-lit environments. Moreover, it was noted that there are two morphological forms of this species: slender, elongated animals have larger and more numerous cerata, whereas stubby animals have fewer and much smaller cerata.

\section{Incertae sedis}

\section{Eolid sp. 1 (Figs. 48, 49)}

MorphOLOGY. The animals presented a greytransparent body colouration. Along the entire body surface there were many bright white dots. The rhinophores and the oral tentacles were smooth. The former had the proximal parts grey-transparent coloured with scattered white dots. Instead, the distal portions were opalescent white. The rhinophores were brownish coloured at half-height. The oral ten- 
tacles were opalescent white for most of their length. The head's sides seemed to be hollowed out. The cerata were transparent and, through them, the cream-coloured digestive gland's branches could be noted. These lasts presented the distal parts red and the tips grey coloured. The tail was elongated and pointed. One of the two individuals was missing of one oral tentacle, and it had more swollen cerata.

Abundance. Only two specimens were found during this study. This nudibranch can be considered as rare.

LOCATION AND DEPTH. The animals were documented in Santa Tecla and Santa Maria La Scala at 5 and $4.8 \mathrm{~m}$ of depth respectively.

SubStRATES AND habitats. The nudibranchs were observed on Peyssonnelia sp. and on a Rhodymenia $\mathrm{sp}$. thallus covered by red and brown algae.

\section{SEASONALITY. October and November.}

REMARKS. The two individuals did not match with none of the species known by the author.

\section{DISCUSSION AND CONCLUSIONS}

Through this study new information, about cladobranch species present along the central-eastern coast of Sicily, have been provided. The number of species related to this suborder increased to 38 , compared with the 34 species highlighted by Lombardo \& Marletta (2020a). Consequently, along the examined areas from 2017 to the first months of 2021 it was documented about the $30 \%$ of all the Mediterranean species of cladobranchs [considered Trainito \& Doneddu (2014)]. Moreover, beyond the new information on each analysed species, this study highlights: i) that in the list of Lombardo \& Marletta (2020a) the specimens determined as "Trinchesia caerulea" belong to a complex of species considered by Korshunova et al. (2019) as two taxonomic entities clearly distinguishable, $T$. caerulea (Montagu, 1804) and T. morrowae Korshunova et al. 2019; ii) the first Mediterranean report of Trinchesia cf. diljuvia Korshunova et al., 2019; iii) the finding of a unidentified species, belonging to the genus Berghia, never seen in this area; iiii) the observation of a new eolid, which could not be determined in any way.

\section{ACKNOWLEDGEMENTS}

The author thanks a lot Dr. Giuliana Marletta for its constant presence during the scuba dives and for her precious suggestions.

\section{REFERENCES}

Bouchet P., Rocroi J.P., Hausdorf B., Kaim A., Kano Y., Nützel A., Parkhaev P., Schrödl M. \& Strong E.E., 2017. Revised Classification, Nomenclator and Typification of Gastropod and Monoplacophoran $\mathrm{Fa}$ milies. Malacologia, 61: 1-526. https://doi.org/10.4002/040.061.0201

Cormaci M., Furnari G., Catra M., Alongi G. \& Giaccone G., 2012. Flora marina bentonica del Mediterraneo: Phaeophyceae. Bollettino dell'Accademia Gioenia di Scienze Naturali, 45 (375): 1-508.

Cormaci M., Furnari G. \& Alongi G., 2014. Flora marina bentonica del Mediterraneo: Chlorophyta. Bollettino dell'Accademia Gioenia di Scienze Naturali, 47 (377): 11-436.

Cormaci M., Furnari G. \& Alongi G., 2017. Flora marina bentonica del Mediterraneo: Rhodophyta (Rhodymeniophycidae escluse). Bollettino dell'Accademia Gioenia di Scienze Naturali, 50 (380): 1-391.

Cormaci M., Furnari G. \& Alongi G., 2020. Flora marina bentonica del Mediterraneo: Rhodophyta - Rhodymeniophycidae I. Acrosymphytales, Bonnemaisoniales, Gelidiales, Gigartinales, Gracilariales. Bollettino dell'Accademia Gioenia di Scienze Naturali, 53 (383): 1-346.

Franc A., 1968. Sous-Classe Des Opisthobranches. In: Grassé P.P., Traité de Zoologie, Anatomie, Systématique, Biologie. V (III): Mollusques Gastéropodes et Scaphopodes. Masson \& Cie., Paris, 608-893.

Gerovasileiou V., Akyol O., Al-Hosne Z., Alshikh Rasheed R., Ataç E., Bello G., Ćetković I., CorsiniFoka M., Crocetta F., Denitto F., Guidetti P., Gül B., Insacco G., Jimenez C., Licchelli C., Lipej L., Lombardo A., Mancini E., Marletta G., Michailidis N., Pešić A., Poursanidis D., Refes W., Sahraoui H., Thasitis I., Tiralongo F., Tosunoğlu Z., Trkov D., Vazzana A. \& Zava B., 2020. New records of rare species in the Mediterranean Sea (May 2020). Mediterranean Marine Science, 0: 340-359.

https://doi.org/10.12681/mms.22148

Goodheart J.A., 2017. Insights into the Systematics, Phylogeny, and Evolution of Cladobranchia (Gastropoda: Heterobranchia). American Malacological Bullettin, 35: 73-81. http://dx.doi.org/10.4003/006.035.0111

Korshunova T., Picton B., Furfaro G., Mariottini P., Pontes M., Prkić J., Fletcher K., Malmberg K., Lundin 
K. \& Martynov A., 2019 Multilevel fine-scale diversity challenges the 'cryptic species' concept. Scientific Reports, 9: 6732. https://doi.org/10.1038/s41598-019-42297-5

Lance J.R., 1962. A new species of Armina (Gastropoda, Nudibranchia) from the Gulf of California. Veliger, 5: 51-54.

Lombardo A. \& Marletta G., 2019. Presence of the alien species Godiva quadricolor (Barnard, 1927) (Gastropoda Nudibranchia Facelinidae) along the coast of eastern Sicily. Biodiversity Journal, 10: 147-150. https://doi.org/10.31396/Biodiv.Jour.2019.10.2.147.150

Lombardo A. \& Marletta G., 2020a. The biodiversity of the marine Heterobranchia fauna along the centraleastern coast of Sicily, Ionian Sea. Biodiversity Journal, 11: 861-870.

https://doi.org/10.31396/Biodiv.Jour.2020.11.4.861.870

Lombardo A. \& Marletta G., 2020b. Antiopella cristata (Delle Chiaje, 1841) (Nudibranchia Janolidae). Biodiversity Journal, 11 I-II. https://doi.org/10.31396/Biodiv.Jour.2020.11.4.I.II

Lombardo A. \& Marletta G., 2020c. New data on the seasonality of Flabellina affinis (Gmelin, 1791) and Cratena peregrina (Gmelin, 1791) (Gastropoda Nudibranchia) in the Ionian Sea, Central Mediterranean. Biodiversity Journal, 11: 1045-1053, https://doi.org/10.31396/Biodiv.Jour.2020.11.4.1045.1053.

Lombardo A., Marletta G. \& Leonardi G., 2020. Seasonality of Edmundsella pedata (Montagu, 1816) (Nudibranchia Flabellinidae) along the Ionian coasts of Sicily (Central Mediterranean Sea). Biodiversity Journal, 11: 631-638. https://doi.org/10.31396/Biodiv.Jour.2020.11.2.631.638

Lombardo A. \& Marletta G., 2021a. New findings of Nudipleura (Mollusca: Gastropoda) along the central-eastern coast of Sicily (Ionian Sea). Thalassia Salentina, 43: 71-82. https://doi.org/10.1285/i15910725v43p71
Lombardo A. \& Marletta G., 2021b. Seasonality and new observations on Dondice banyulensis Portmann \& Sandmeier, 1960 (Gastropoda: Nudibranchia) along the central-eastern coast of Sicily. Bollettino Malacologico, 57: 114-119.

Miller M.C. \& Willan R.C., 1986. A review of the New Zealand arminacean nudibranchs (Opisthobranchia: Arminacea). New Zealand Journal of Zoology, 13: 377-408. https://doi.org/10.1080/03014223.1986.10422671

Odhner N.H.J., 1934. The Nudibranchiata. British Antartic (Terra Nova) Expedition, 1910. British Museum Natural History Report, 7: 229-310.

Odhner N.H.J., 1936. Nudibranchia Dendronotacea a revision of the system. Mémoires du Musée royal d'histoire naturelle de Belgique, 2: 1057-1128.

Pruvot-Fol A., 1954. Faune de France vol. 58. Mollusques Opisthobranches. Paul Lechevalier, Paris, 460 pp.

Schmekel L. \& Portmann A., 1982. Opisthobranchia des Mittelmeeres. Nudibranchia und Saccoglossa. Springer-Verlag., Berlin, Germany, 410 pp.

Thompson T.E. \& Brown G. H., 1984. Biology of Opisthobranch molluscs vol. II. The Ray Society, London, 229 pp.

Trainito E. \& Baldacconi R., 2014. Atlante di flora e fauna del Mediterraneo. Il Castello, Cornaredo, 432 pp.

Trainito E. \& Doneddu M., 2014. Nudibranchi del Mediterraneo. Il Castello, Cornaredo, 192 pp.

Wägele H. \& Willan R.C., 2000. Phylogeny of the Nudibranchia. Zoological Journal of the Linnean Society, 130: 83-181. https://doi.org/10.1111/j.1096-3642.2000.tb02196.x Willan R. \& Morton J., 1984. Marine Molluscs Part 2: Opisthobranchia. Leigh Laboratory Bulletin, 13: 1106. 

